\title{
Pan-African rare metals bearing pegmatites in Wadi Ghadir, South Eastern desert, Egypt: the geochemical evolution and implications for mineralization
}

\author{
Mohamed S. Kamar' ${ }^{1}$ Nasser M. Moghazy ${ }^{1} \cdot$ Gehad M. Saleh ${ }^{1}$
}

Received: 5 September 2020 / Accepted: 23 February 2021 / Published online: 6 March 2021

(C) The Author(s) 2021 OPEN

\begin{abstract}
Quartz-diorites, monzogranites and pegmatites are the main rock units in the studied area. The pegmatites occur as zoned pockets within monzogranites with zonal arrangement: border, wall, intermediate, and core zones. The wall zone have enrichment of radioactive and RREs-bearing minerals. K-feldspar, plagioclase and quartz are essential minerals, whereas uranothorite, columbite, zircon, xenotime, monazite, sphalerite and pyrite are accessories. Geochemically, the pegmatites of W. Ghadir have peraluminous character, ferroan with alkalic-calcic affinity and emplaced in within plate setting. These pegmatites revealed Li-bearing variety and high level of rare earth elements mineralization. The studied pegmatites exhibit high contents of $\mathrm{Li}, \mathrm{Nb}, \mathrm{Cu}, \mathrm{Ta}, \mathrm{U}, \mathrm{Th}, \mathrm{Pb}, \mathrm{Zr}, \mathrm{Zn}$ and $\mathrm{Ga}$, can be from the previous data, the studied pegmatites can be classified as a Niobium-Yttrium-Fluorine (NYF) pegmatite or rare metal pegmatite. The trace elements ratio supports a low degree of fractionation and metasomatism in the evolutionary history of the pegmatites, and the very low Cs values (2.2-4.3 ppm) indicate paucity of alkali metal fractionation. Spectrometric investigation revealed that monzogranites are not uraniferous, while the radioactive anomaly is confined to the pegmatites. Applying the $U$ mobilization equation proved that pegmatite samples have been originated from a late magmatic phase of magma very rich in radioelements, and the pegmatites affected with hydrothermal solutions rich in uranium than thorium which indicates uranium addition. Radioactive and important heavy minerals are represented by uranothorite, columbite, zircon, monazite, xenotime, sphalerite and pyrite.
\end{abstract}

Keywords Rare Metals Pegmatite · Geochemistry ·W. Ghadir · Eastern Desert · Uranium · Egypt

\section{Introduction}

Pegmatites define as a case of highly evolved granitic melts which result of protracted fractional crystallization [41] and are of scientific interest as they display complex and diverse textures, mineralogy, structures, and petrogenetic relationships, with evolved geochemical signatures, which have challenged petrologists in terms of the origin and processes of formation.

Pegmatites represent an important source of rare metals, such as $\mathrm{Li}, \mathrm{Rb}, \mathrm{Cs}$ and $\mathrm{Ta}$. In addition, they have been considered a potential source of other rare metals, such as $\mathrm{Ga}, \mathrm{Be}, \mathrm{Sn}, \mathrm{U}, \mathrm{Nb}, \mathrm{Hf}$, among others [38]. Pegmatites are, in addition, a source for high-quality industrial minerals (mainly feldspars, kaolinite, quartz, micas, and spodumene for ceramics) or gemstones such as topaz, tourmaline, aquamarine, spodumene, among others [41].

C'erny' [14] defined the 'pegmatite group' as the basic genetic unit of association among individual pegmatite bodies. Differentiation seen in a group of pegmatite dikes is thought to originate from differentiation of a common source pluton, such that continuous or episodic melt extraction, coupled with continuous crystallization, produces the regional zonation toward more fractionated,

Nasser M. Moghazy, nassmoghazy@yahoo.com | 1 Nuclear Materials Authority, El-Maadi, P.O. Box 530, Cairo, Egypt. 
distal pegmatites (e.g., Trueman and Cerny [62]; Černý [15]).

Cerný and Ercit [13] classified the pegmatites based on the work of Ginsburg et al. [24] into three families considers a combination of emplacement, depth, metamorphic grade, and minor element contents: (I) Lithium-Cesium-Tantalum (LCT) pegmatites,(II) Niobium-Yttrium-Fluorine (NYF) pegmatites and (III) Mixed LCT-NYF pegmatites. The high-field-strength element (W, $\mathrm{Zr}, \mathrm{Nb}, \mathrm{Ta}, \mathrm{Ti}, \mathrm{Sn}, \mathrm{Hf}$, Th, and $\mathrm{U}$ ) oxides found in pegmatites are of particular interest in industry owing to their use in high-tech commodities, and to scientists, as recorders of pegmatite evolution. However, the investigations are generally focused on the most evolved granitic pegmatites of LCT geochemical signature, especially in the REL-Li subclass [23].

Most of radioactive occurrences in the basement rocks of Egypt are located in the younger granites and related pegmatites. The latter have been considered as favorable uranium and thorium mineralization environments [50]. Many localities in the Eastern Desert of Egypt have a radioactive pegmatites, e.g., the pegmatitic bodies of the Gabal Ras Baroud younger granites [53] uranium and columbite mineralization in the pegmatites related to the Gabal Abu Dob younger granites [27], and radioactive pegmatites related to the Gabal El-Sibai alkali feldspar granites [2]. Anomalous pegmatites associated with granitic rocks have also been reported in the southern part of the Eastern Desert [3, 28], Abdel Warith el al. [1]. The high level of radioactivity of these rocks is attributed to the presence of accessory minerals such as zircon, monazite, thorite, uranothorite and allanite [57]. Uranium and thorium are generally enriched in the youngest, most felsic and most potassic members of comagmatic suites of igneous rocks [54].

The study of $\mathrm{Nb}$-Ta minerals is of great interest from both economic and scientific point of view. New high technologies [38] and 2014), especially those for the manufacture of electronic devices of small dimensions, have caused an increase in the need for tantalum [42] and [48]. Columbite-group minerals with a chemical formula $(\mathrm{Fe}, \mathrm{Mn})(\mathrm{Nb}, \mathrm{Ta})_{2} \mathrm{O}$ are the most important minerals in which $\mathrm{Nb}$ and Ta are major components. They commonly occur in pegmatites and highly evolved granites Cerny and Ercit $[12,20]$. Recent studies show that the chemistry of columbite-group minerals possibly reflects the chemistry of magma sources and pegmatite melts [46]. These compositional variations of columbite-group minerals can potentially reveal fractionation of pegmatite melts as well as hydrothermal evolution of pegmatites [4].

Columbite-tantalite minerals commonly have a broad range of $U$ contents that may reach several thousand ppm and may substitute Fe and Mn in their crystal lattice, but for high U-contents may form phases of its own (e.g., uraninite, [55]). Rare metal pegmatites are small and chemically highly evolved portions of much larger composite granite intrusions which themselves form granite provinces and reflect episodes of partial melting in the lower continental crust (Cerný 1982). Pegmatite melts are enriched in volatile and incompatible components (incompatible with respect to the main granitic mineral phases) and may move along fractures up to several kilometers away from their igneous parent intrusions due to low viscosity and low density [33].

The present study aims to describe the geology, petrography, and geochemistry of rare-metal-bearing pegmatites in W. Ghadir, south Eastern Desert, Egypt, and focuses on geochemical evolution and mineralization.

\section{Geological setting}

El-Sharkawy and El-Bayoumi [19] classified the rocks that crop out along the eastern Ghadir as granites belonging to the older and younger (Gattarian) granites. Takla et al. [59] classified the granitoids of W. Ghadir as (a) diorites and granodiorites, which have similar characteristics to the older granites and (b) the younger granites that have similar characteristics to alkali and other anorogenic granitic suits. Ibrahim and Ali [29] subdivided the granitoid rocks in the Ghadir area according to their field relationships, petrography and geochemical characteristics into two types - the first one includes quartz diorite and gneissose granodiorite. They have a metaluminous characteristic and were emplaced during pre-plate collision under high water-vapor pressure and the second one is represented by perthitic leucogranite and muscovite-biotite granite. They were emplaced during syn-collision at moderate water-vapor pressure. Kamar [35] classified the pegmatites in W. Ghadir into zoned pockets and zoned lenses (fractured). The zoned pegmatite pockets have gradational contacts with its host monzogranite and have the following zonal arrangement: border, intermediate, and core zones. They can be considered as anomalous granites. The zoned pegmatite lenses are structurally controlled as they are arranged in more or less one trend along the fracture with a major fault striking NE-SW. They have intermediate and core zones. He also classified the heavy minerals into several groups according to its anion groups: (1) silicate (thorite), (2) carbonate (bastnäsite), (3) fluoride (fluorite), (4) oxides (columbite and hematite), (5) sulfide (pyrite), and (6) hydroxide (goethite and illite). Mahmoud et al. [43] classified the granitoid rocks to granodiorites and syenogranites. They recorded monazite, pseudoautunite, goethite, hematite, pyrite, cinnabar, wulfenite, galena, natro-jarosite, titanite, and anatase in the stream 
sediments. Khaleal et al. [36] studied the granitoid rocks north W. Ghadir and classified them into, quartz-diorite, granodiorite and monzogranite. The fresh monzogranite suffered alteration processes and rich in sulfides. The propylitic alteration as well as the K-metasomatism is the main alteration types in the altered monzogranite, while plagioclase destructed and formed epidote. The identified heavy minerals are mostly pyrite, sphalerite, galena, monazite, hematite and goethite EPMA analyses proved that pyrite mineral is rich in $\mathrm{Co}$ and Se and low values of $\mathrm{Mn}$ and $\mathrm{Cu}$.

The studied area is nearly located at the middle part of W. Ghadir, lying at about $30 \mathrm{~km}$ south of Marsa Alam
City between latitudes $24^{\circ} 48^{\prime} 09^{\prime \prime}$ and $24^{\circ} 49^{\prime} 33^{\prime \prime} \mathrm{N}$ and longitudes $34^{\circ} 52^{\prime} 05^{\prime \prime}$ and $34^{\circ} 54^{\prime} 05^{\prime \prime} \mathrm{E}$ (Fig. 1).

This area was previously mapped by Takla et al. [58, 59], and they interpreted its geologic history as the following: (1) Old metamorphic rocks, composed of biotite granodiorite gneisses, migmatitic granite gneisses, granite mobilizates and amphibolite enclaves, (2) Ophiolitic mélange and (3) Intrusive granitoids that composed of diorites, granodiorites and granites.

The studied area (Fig. 1) is characterized by lowto-moderate relief and consists of older and younger
Fig. 1 a Location and b

detailed geological maps of $W$. Ghadir area, SED, Egypt (modified after [58])

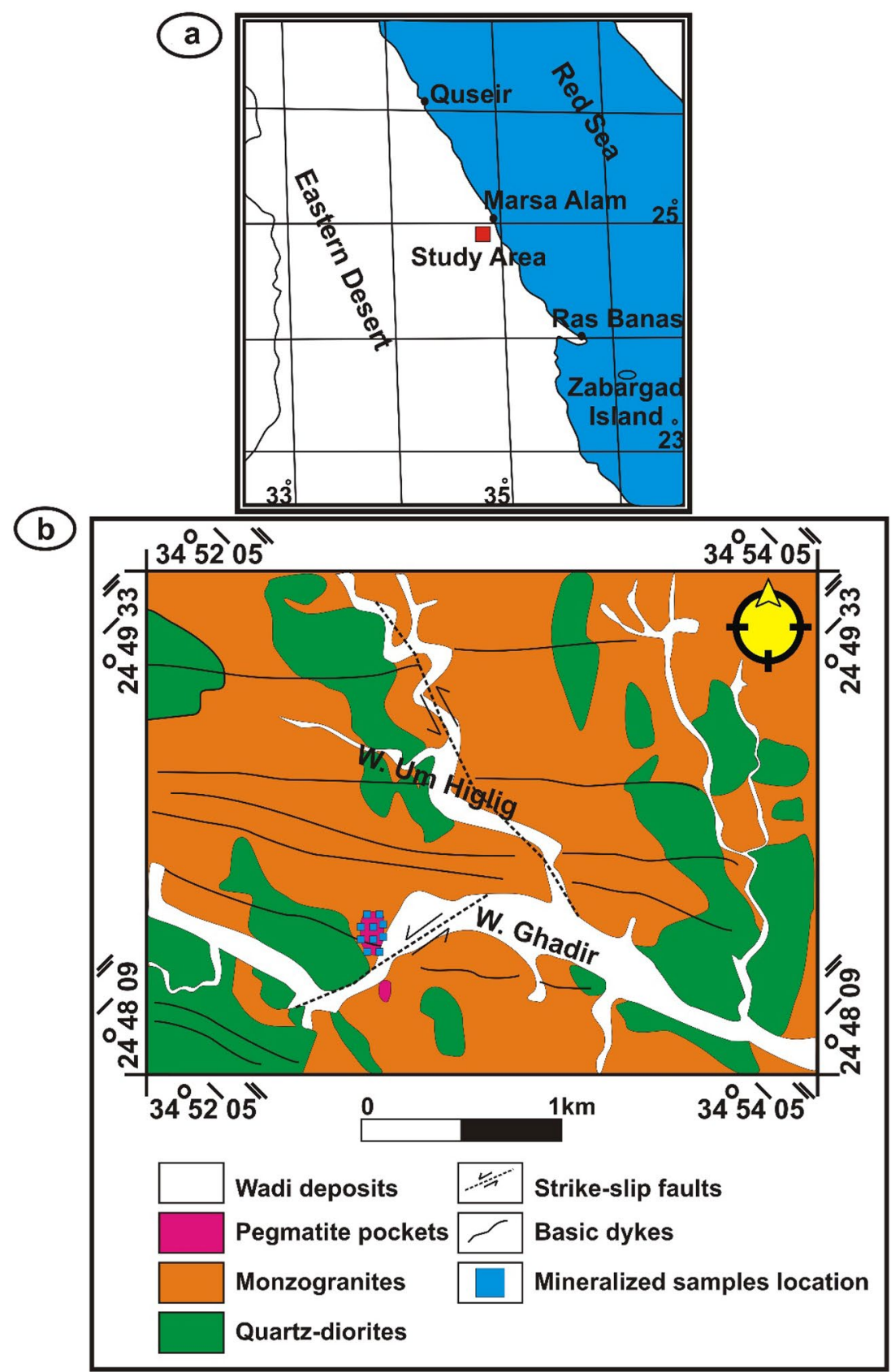


granitic rocks. These rocks are classified into quartzdiorite, monzogranites and pegmatites.

The quartz diorites are dark greenish gray color and medium- to coarse-grained. These rocks are cavernous, exfoliated, jointed, faulted and dissected by basic dykes. They are intruded by monzogranites with sharp intrusive contacts. The monzogranites are medium-to coarsegrained with a pink color forming moderate relief mountain terrains. They attain cavernous weathering, exfoliation and joints (Fig. 2a) and also dissected by basic dykes. Many of these joints are filled by copper mineralization and/or pegmatite veins. Some fractures exhibit alteration products represented by hematization and silicification and record high radioactivity rather than the surrounding fresh monzogranites.

The pegmatites occur as zoned pockets within the monzogranites. These pockets range in dimension from 4 to $30 \mathrm{~m}$ in width and from 10 to $50 \mathrm{~m}$ in long. They have gradational contacts with its host monzogranites, and also dissected by basic dykes (Fig. $2 \mathrm{~b}$ and c). The pegmatite pockets have the following zonal arrangement: border, wall, intermediate, and core zones (Fig. 2d). Border zones consist of a thin fine-grained granitic rock at the contact with host rock. Inward from the border, the wall zone is marked by an abrupt increase in crystal size and characterized by the presence of significant mineralization. The intermediate zone forms gradational contacts with wall zone and larger in crystal size, where intergrowths resulting in K-feldspar and quartz of large crystal size. The core zone formed only from pure quartz or/and K-feldspars. Sometimes quartz is highly shearing specially at the fault zone (Fig. 2e). The wall zone is characterized by visible columbite mineral (Fig. 2f).

\section{Methodology}

Ten representative pegmatite samples were analyzed for their major, trace elements and rare earth elements at the ACME Analytical Laboratory, Vancouver, Canada. Major element contents were determined by ICP-ES (inductively coupled plasma emission spectrometry). Trace elements (including REEs) were also determined by ICP-MS (inductively coupled plasma mass spectrometry). The LOI (loss on ignition) values were measured on the basis of weighting the samples before and after one hour of heating at $1000^{\circ} \mathrm{C}$. The data of the analytical samples are tabulated in supplementary Tables (Tables 1, 2 and 3).

Field ground $\gamma$-ray spectrometry survey has been done using $\gamma$-ray spectrometric multichannel analyzer instrument model RS-230 Canadian Type. Ground $\gamma$-ray spectrometric survey can detect dose rate (D.R.) in unit (nanosieverts per hour $\left.\left(\mathrm{nSvh}^{-1}\right)\right)$, potassium (K\%), equivalent uranium content (eU ppm), and equivalent thorium content (eTh ppm).

The selected samples of pegmatites have been crushed to -60 mesh size followed the quartering of crushed sample to obtain representative sample of about $100 \mathrm{~g}$ for each one. Bromoform (sp. gr. =2.89) were used to separate heavy minerals. The magnetite was separated from each heavy fraction by using a hand magnet. The magnetite free fractions were fractionated using the Frantz isodynamic separator at $0.08,0.2,0.5,1.0$ and $1.5 \mathrm{~A}$. This was followed by hand picking under binocular microscope in order to obtain pure mineral separates. Thin polished sections and separated grains were identified by Scanning Electron Microscope (SEM) back-scattered images supported by energy-dispersive spectrometer (EDS) unit (model Philips XL 30 SEM) at the laboratory of the Nuclear Materials Authority (NMA) of Egypt.

\section{Results}

\subsection{Petrography}

Petrographically, the monzogranite is essentially composed of quartz, k-feldspar, plagioclases and biotite. Opaques and zircon are accessory minerals. Chlorite, epidote and sericite are secondary minerals. Quartz occur as anhedral crystals of various shape and size, showing moderate to strong undulose extinction but sometimes show uniform extinction due to secondary quartz. Quartz crystals sometimes show evidence of ductile and brittle deformation and displacement as strike slip faults along fault planes (Fig. 3a). K-feldspar is represented by microcline perthite with some minor amount of orthoclase perthite, showing simple twinnings. They are corroded with secondary quartz crystals along their peripheries. Plagioclases occur as subhedral to anhedral tabular crystals of albite-oligoclase in composition. They are cloudy crystals due to partial alteration to sericite and secondary muscovite exhibiting certain twin lamellae at the core of crystals. Sometimes, they enclose zircon, opaques and anhedral quartz as inclusions. Biotite occurs as subhedral to anhedral tabular or flaky crystals, show slight altered to pale green chlorite and iron oxides along their cleavage planes. Opaque minerals occur as irregular patches related to biotite, scattered between essential minerals. Zircon (Fig. 3b) and epidote occur as subhedral crystals enclosed within biotite and feldspars.

The pegmatite (wall zone) shows evidence of post-crystallization hydrothermal alteration in thin section, especially along joint planes which filled by radioactive-bearing minerals and opaques. The pegmatite is essentially composed of K-feldspar, which is mostly represented by 
Fig. 2 a Sub-vertical jointing in monzogranites, W. Ghadir, SED, Egypt. Looking NE b and c: Gradational contact between pegmatite body and its hosting monzogranites, W. Ghadir, SED, Egypt. And Notice, a basic dyke is cutting both of them and affected by a left lateral strike-slip fault. d Sketch showing zonation order in pegmatite pockets and its relation with hosting rock, W. Ghadir, SED, Egypt. e Pegmatite pocket mainly composed of K-feldspar and quartz (sheared qz), $\mathrm{W}$. Ghadir, SED, Egypt. f Visible columbite in K-feldspar of pegmatite pocket, W. Ghadir, SED, Egypt
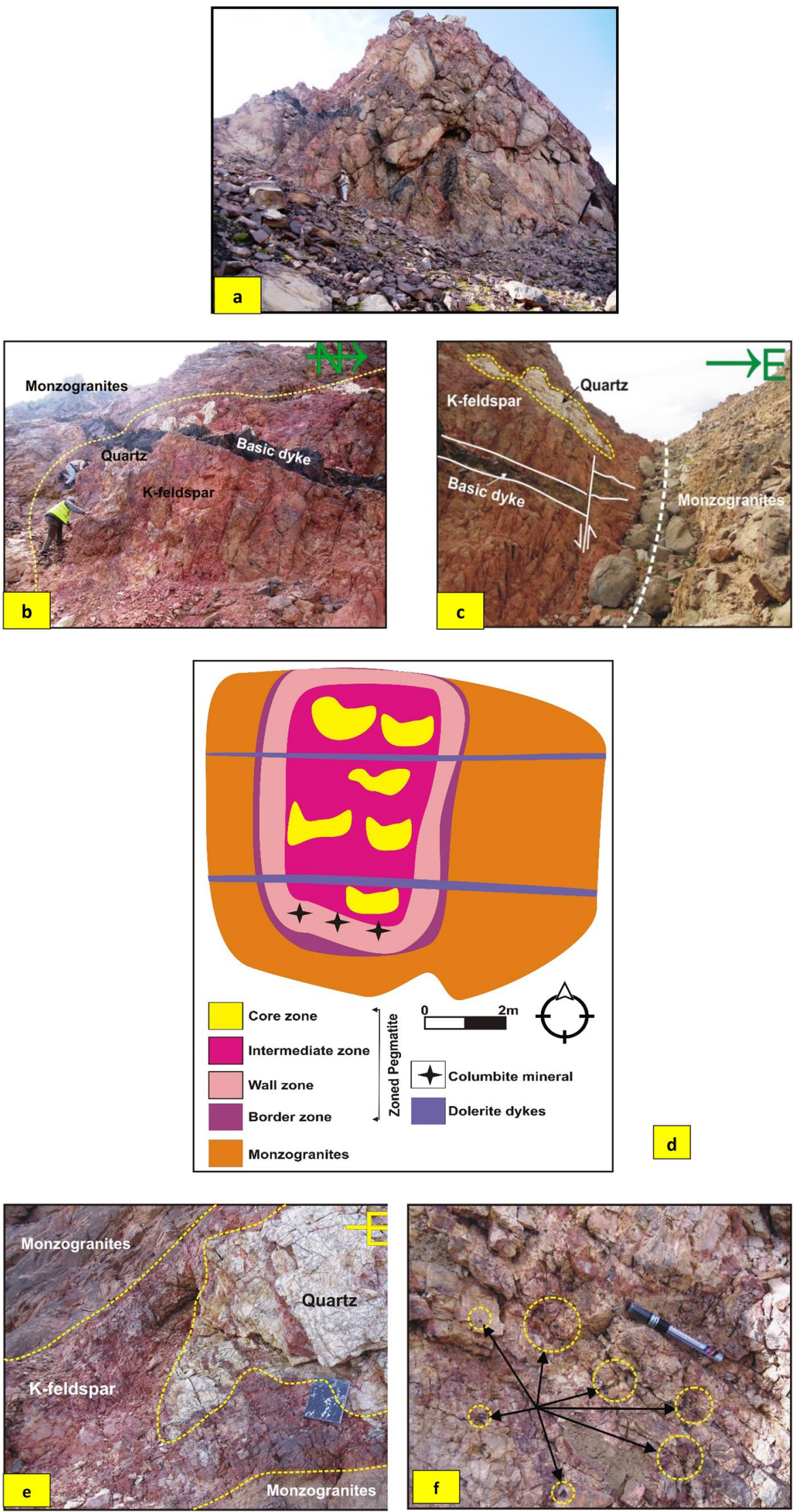

SN Applied Sciences

a SPRINGER NATURE journal 
Table 1 Major oxides and CIPW norm for the studied granitic pegmatite, W. Ghadir area, SED, Egypt

\begin{tabular}{|c|c|c|c|c|c|c|c|c|c|c|}
\hline S. no & GP1 & GP2 & GP3 & GP4 & GP5 & GP6 & GP7 & GP8 & GP9 & GP10 \\
\hline $\mathrm{SiO}_{2}$ & 72.6 & 72.2 & 69.3 & 72.5 & 72.8 & 73.4 & 73.1 & 72.9 & 72.1 & 73.2 \\
\hline $\mathrm{TiO}_{2}$ & 0.06 & 0.05 & 0.11 & 0.07 & 0.09 & 0.08 & 0.07 & 0.04 & 0.08 & 0.06 \\
\hline $\mathrm{Al}_{2} \mathrm{O}_{3}$ & 14.25 & 13.87 & 15.34 & 13.81 & 13.60 & 13.66 & 12.81 & 13.59 & 14.11 & 12.85 \\
\hline $\mathrm{Fe}_{2} \mathrm{O}_{3}{ }^{t}$ & 3.50 & 3.87 & 4.95 & 2.87 & 3.20 & 2.80 & 5.22 & 3.63 & 3.02 & 3.06 \\
\hline $\mathrm{MgO}$ & 0.13 & 0.15 & 0.27 & 0.18 & 0.23 & 0.17 & 0.18 & 0.10 & 0.18 & 0.15 \\
\hline $\mathrm{MnO}$ & 0.07 & 0.06 & 0.16 & 0.06 & 0.08 & 0.08 & 0.23 & 0.11 & 0.05 & 0.03 \\
\hline $\mathrm{CaO}$ & 0.35 & 0.41 & 0.55 & 0.57 & 0.45 & 0.50 & 0.84 & 0.38 & 0.53 & 0.42 \\
\hline $\mathrm{K}_{2} \mathrm{O}$ & 3.65 & 3.58 & 3.94 & 4.32 & 4.28 & 4.25 & 3.76 & 3.60 & 3.59 & 4.26 \\
\hline $\mathrm{Na}_{2} \mathrm{O}$ & 4.80 & 5.32 & 4.81 & 5.03 & 4.62 & 4.82 & 2.97 & 5.11 & 5.56 & 4.27 \\
\hline $\mathrm{P}_{2} \mathrm{O}_{5}$ & 0.02 & 0.04 & 0.04 & 0.02 & 0.02 & 0.02 & 0.03 & 0.02 & 0.04 & 0.02 \\
\hline LOI & 0.7 & 0.4 & 0.6 & 0.5 & 0.7 & 0.4 & 0.8 & 0.5 & 0.7 & 0.9 \\
\hline total & 100.13 & 99.95 & 100.05 & 99.95 & 100.07 & 100.18 & 100.01 & 99.98 & 99.96 & 99.22 \\
\hline \multicolumn{11}{|c|}{ CIPW-norm } \\
\hline $\mathrm{Q}$ & 29.84 & 26.60 & 24.72 & 25.36 & 28.35 & 27.83 & 39.49 & 28.48 & 24.74 & 30.97 \\
\hline C & 1.81 & 0.607 & 2.28 & 0 & 0.62 & 0.258 & 2.41 & 0.641 & 0.21 & 0.48 \\
\hline Or & 21.57 & 21.14 & 23.28 & 25.56 & 25.27 & 25.13 & 22.21 & 21.29 & 21.21 & 25.20 \\
\hline$A b$ & 40.85 & 45.008 & 40.67 & 42.52 & 39.066 & 40.78 & 25.09 & 43.28 & 47.016 & 36.13 \\
\hline An & 1.63 & 1.74 & 2.44 & 2.36 & 2.07 & 2.38 & 3.97 & 1.73 & 2.40 & 1.98 \\
\hline Di & 0.00 & 0 & 0 & 0.26 & 0 & 0 & 0 & 0 & 0 & 0 \\
\hline $\mathrm{Hy}$ & 0.33 & 0.37 & 0.66 & 0.33 & 0.58 & 0.41 & 0.45 & 0.25 & 0.45 & 0.37 \\
\hline Mt & 0.05 & 0.044 & 0.206 & 0 & 0 & 0.05 & 0.545 & 0.25 & 0 & 0 \\
\hline II & 0.12 & 0.10 & 0.20 & 0.13 & 0.17 & 0.15 & 0.14 & 0.07 & 0.12 & 0.07 \\
\hline $\mathrm{Hm}$ & 3.47 & 3.845 & 4.805 & 2.87 & 3.203 & 2.77 & 4.84 & 3.46 & 3.02 & 3.06 \\
\hline Tn & 0.00 & 0.00 & 0.00 & 0.01 & 0.00 & 0.00 & 0.00 & 0.00 & 0.00 & 0.00 \\
\hline $\mathrm{Ru}$ & 0.00 & 0 & 0 & 0 & 0.001 & 0 & 0 & 0 & 0.016 & 0.027 \\
\hline$A p$ & 0.04 & 0.10 & 0.10 & 0.05 & 0.05 & 0.04 & 0.07 & 0.05 & 0.09 & 0.04 \\
\hline
\end{tabular}

$\mathrm{Fe}_{2} \mathrm{O}_{3}{ }^{\mathrm{t}}=$ total iron as $\mathrm{Fe}_{2} \mathrm{O}_{3}$

both orthoclase and orthoclase microperthite. Orthoclase occurs as euhedral to subhedral crystals and shows simple twinning. The microperthite are slightly altered to kaolinite. Quartz occurs as subhedral to anhedral crystals, with some crystals showing undulose extinction and irregular boundaries. Plagioclase exists as euhedral to subhedral crystals and has albite $\left(\mathrm{An}_{6-10}\right)$ composition. It exhibits albite and Carlsbad twinning and sometimes forms antiperthite texture. Partial alteration to kaolinite and sericite is developed. Local strain affecting pegmatites results in distortion of twinning in plagioclase crystals (Fig. 3c). Biotite occurs as subhedral flakey crystals and engulfing opaque minerals. Muscovite forms subhedral to anhedral flakey crystals and mostly filling the interstitial spaces between the major constituents especially plagioclase (Fig. 3d and e). Titanite forms subhedral to anhedral rhombic crystals and are associated with biotite. Opaques occur as subhedral to anhedral crystals usually filling the fractures and joints planes especially in plagioclases (Fig. 3 f).
The doleritic dyke is fine- to medium-grained with dark green to light green colors. They are mainly composed of plagioclases, pyroxene, hornblende and opaque minerals. Plagioclases occurs as fine- to medium-grained subhedral to anhedral crystals of andesine to labradorite $\left(\mathrm{An}_{46}{ }^{-}{ }_{58}\right)$ in composition. They exhibits albite and albite/ Carlsbad twinning and shows partial to complete alteration to saussurite and calcite (Fig. 3g). Pyroxene is represented by augite (Fig. $3 \mathrm{~h}$ ) and occurs as subhedral to anhedral crystals. It shows alteration to tremolite and actinolite due to deuteric effects. Hornblende exists as subhedral to anhedral crystals and shows partial to complete alteration to chlorite especially along the cleavage planes and crystal boundaries. Opaque minerals occur as anhedral crystals and associated with the mafic constituents. Titanite forms anhedral crystals associated with plagioclases and ferromagnesian minerals. 
Table 2 Trace elements concentration (ppm) and geochemical parameters for granitic pegmatite of W. Ghadir area, SED, Egypt

\begin{tabular}{|c|c|c|c|c|c|c|c|c|c|c|}
\hline S. no & GP1 & GP2 & GP3 & GP4 & GP5 & GP6 & GP7 & GP8 & GP9 & GP10 \\
\hline Mo & 11.97 & 6.3 & 26.88 & 9.49 & 8.21 & 5.16 & 87.17 & 14.3 & 6.22 & 5.15 \\
\hline $\mathrm{Cu}$ & 419.2 & 122.2 & 212.8 & 73.3 & 157.6 & 46.3 & 695.9 & 153.6 & 95.4 & 49.4 \\
\hline $\mathrm{Pb}$ & 2978.24 & 133.75 & 891.66 & 220.54 & 411.43 & 111.41 & 4902.89 & 336.44 & 185.69 & 44.72 \\
\hline $\mathrm{Zn}$ & 900.4 & 1225 & 694.2 & 496.5 & 4847.7 & 249.3 & 2169.3 & 725.2 & 620.2 & 447.8 \\
\hline $\mathrm{Ni}$ & 4 & 4.2 & 7.5 & 5.6 & 17 & 4.6 & 11 & 3.4 & 5.9 & 4.4 \\
\hline Co & 1.9 & 2.3 & 3.8 & 3.3 & 4.6 & 3.4 & 3.4 & 1 & 3.5 & 2.9 \\
\hline As & 2115 & 5.5 & 4.2 & 12.2 & 17.5 & 3.2 & 270 & 64.9 & 5.6 & 3.8 \\
\hline$U$ & 1120.7 & 114.7 & 118.4 & 85.5 & 245.8 & 79.8 & 933.1 & 82.9 & 156.2 & 71.7 \\
\hline Th & 470.8 & 4000 & 1942.9 & 265.2 & 359.5 & 300 & 902.2 & 2551.9 & 2787.5 & 154.9 \\
\hline $\mathrm{Sr}$ & 77 & 32 & 45 & 43 & 34 & 33 & 67 & 40 & 38 & 32 \\
\hline $\mathrm{Bi}$ & 32.12 & 34.18 & 46.3 & 10.5 & 15.68 & 13.05 & 107.28 & 17.8 & 24.68 & 15.64 \\
\hline V & 7 & 4 & 9 & 6 & 7 & 6 & 7 & 3 & 5 & 5 \\
\hline $\mathrm{Cr}$ & 17 & 7 & 17 & 17 & 19 & 7 & 53 & 21 & 8 & 7 \\
\hline $\mathrm{Ba}$ & 176 & 84 & 102 & 87 & 105 & 85 & 122 & 91 & 91 & 87 \\
\hline W & 18.2 & 16.1 & 18.8 & 14.5 & 20 & 10 & 19 & 13.1 & 11.3 & 9.8 \\
\hline $\mathrm{Zr}$ & 242.4 & 423.6 & 403.4 & 428.4 & 513.3 & 360.1 & 657 & 392.3 & 425.2 & 332.2 \\
\hline Sn & 53.6 & 22 & 19 & 23.3 & 19.6 & 19.8 & 192.8 & 70.3 & 18.6 & 14 \\
\hline $\mathrm{Be}$ & 7 & 162 & 5 & 8 & 8 & 9 & 15 & 32 & 100 & 7 \\
\hline Sc & 1.7 & 2.3 & 1.7 & 1.5 & 1.5 & 1.5 & 3.7 & 2.2 & 2 & 1.4 \\
\hline$Y$ & 396.2 & 319.5 & 179.6 & 125.5 & 176.8 & 98.1 & 738.9 & 237 & 264 & 80.6 \\
\hline $\mathrm{Hf}$ & 18.09 & 23.63 & 30.61 & 30.1 & 36.66 & 27.04 & 44.53 & 26.34 & 28.69 & 20.4 \\
\hline $\mathrm{Li}$ & 139.2 & 905.5 & 292.2 & 103.1 & 284.9 & 576.6 & 492 & 552.7 & 547.1 & 111.8 \\
\hline $\mathrm{Rb}$ & 452.9 & 539.9 & 489.3 & 488.3 & 602.6 & 677.1 & 706.6 & 615.1 & 340.7 & 471.5 \\
\hline $\mathrm{Ta}$ & 114.3 & 73.6 & 132 & 97.4 & 81.4 & 61.7 & 150.5 & 100.7 & 78.4 & 50.9 \\
\hline $\mathrm{Nb}$ & 797.72 & 533.56 & 903.57 & 708.79 & 631.56 & 544.2 & 1341.9 & 783.21 & 786.2 & 417.64 \\
\hline $\mathrm{Cs}$ & 2.2 & 4.3 & 3.2 & 3.2 & 3 & 2.8 & 2.4 & 3.9 & 2.6 & 3.3 \\
\hline Ga & 62.91 & 69.61 & 64.83 & 64.26 & 66.39 & 60.48 & 61.56 & 71.31 & 68.32 & 55.96 \\
\hline \multicolumn{11}{|c|}{ Geochemical parameters } \\
\hline $\mathrm{Nb} / \mathrm{Ta}$ & 6.98 & 7.25 & 6.845 & 7.277 & 7.759 & 8.82 & 8.92 & 7.78 & 10.03 & 8.205108 \\
\hline $\mathrm{Zr} / \mathrm{Hf}$ & 13.40 & 17.93 & 13.18 & 14.23 & 14.0 & 13.32 & 14.75 & 14.89 & 14.82 & 16.28431 \\
\hline $\mathrm{K} / \mathrm{Cs}$ & $16,590.45$ & 8320.06 & $12,309.37$ & $13,513.96$ & $14,254.28$ & $15,186.4$ & $15,659.63$ & 9235.17 & $13,806.42$ & $12,921.93$ \\
\hline $\mathrm{K}_{2} \mathrm{O} / \mathrm{Rb}$ & 0.008 & 0.0066 & 0.008 & 0.0089 & 0.0071 & 0.0063 & 0.0053 & 0.0059 & 0.011 & 0.009044 \\
\hline $\mathrm{K} / \mathrm{Rb}$ & 80.59 & 66.26 & 80.50 & 88.56 & 70.96 & 62.80 & 53.19 & 58.55 & 105.36 & 90.43983 \\
\hline $\mathrm{K} / \mathrm{Ba}$ & 207.38 & 425.91 & 386.18 & 497.07 & 407.27 & 500.26 & 308.06 & 395.79 & 394.47 & 490.14 \\
\hline $\mathrm{Rb} / \mathrm{Sr}$ & 5.88 & 16.87 & 10.87 & 11.36 & 17.72 & 20.52 & 10.55 & 15.38 & 8.97 & 14.73 \\
\hline Th/U & 0.42 & 34.87 & 16.41 & 3.10 & 1.46 & 3.76 & 0.97 & 30.78 & 17.85 & 2.16 \\
\hline $\mathrm{Y} / \mathrm{Ho}$ & 22.13 & 21.73 & 18.14 & 17.93 & 18.61 & 18.17 & 20.87 & 19.92 & 22.76 & 18.74 \\
\hline
\end{tabular}

\section{Geochemistry of pegmatite}

\subsection{Geochemical characteristics of major oxides and selected trace elements}

The whole-rock major and trace element compositions for W. Ghadir pegmatites are presented in Tables 1 and 2 . Based on the $R_{1}-R_{2}$ discrimination diagram of De La Roche et al. [18], the studied pegmatites plot in alkali feldspar granites field (Fig. 4a). The studied pegmatites are peraluminous magma type on Shand's index diagram (Fig. 4b).
Pearce et al. [51] discriminated between the different tectonic settings of the granitic rocks by plotting $\mathrm{Y}+\mathrm{Nb}$ versus $\mathrm{Rb}$ (Fig. 4c). The figure reveals that the studied pegmatite samples plot in the within plate granite field.

According to the binary relation between $\mathrm{Fe}_{2} \mathrm{O}_{3} /$ $\left(\mathrm{Fe}_{2} \mathrm{O}_{3}+\mathrm{MgO}\right)$ vs. $\mathrm{SiO}_{2}$, pegmatite samples fall in ferroan field (Fig. 4d, [22], Frost and Frost [21]). This is attributed to the variable amounts of biotite, ilmenite and magnetite with various degrees of hematization. Using the $\mathrm{SiO}_{2}$ vs. $\left(\mathrm{Na}_{2} \mathrm{O}+\mathrm{K}_{2} \mathrm{O}-\mathrm{CaO}\right)$ diagram reveals that most of the studied pegmatites plot in the alkalic-calcic field (Fig. 4e [22]). 
Table 3 Rare earth elements concentration (ppm) for granitic pegmatite of W. Ghadir area, SED, Egypt

\begin{tabular}{|c|c|c|c|c|c|c|c|c|c|c|}
\hline S. no & GP1 & GP2 & GP3 & GP4 & GP5 & GP6 & GP7 & GP8 & GP9 & GP10 \\
\hline La & 28.9 & 45.2 & 23.9 & 9.4 & 15.7 & 10.2 & 45 & 25.1 & 38.8 & 8.2 \\
\hline $\mathrm{Ce}$ & 91.24 & 217.47 & 170.57 & 55.61 & 82.49 & 46.75 & 201.92 & 175.56 & 170.03 & 36.76 \\
\hline $\operatorname{Pr}$ & 16.7 & 24.8 & 7.6 & 4.7 & 8.4 & 4.2 & 30.9 & 13.4 & 19.6 & 3 \\
\hline $\mathrm{Nd}$ & 43 & 54 & 17.8 & 11.6 & 20 & 11.3 & 76.9 & 31.4 & 45.4 & 9.3 \\
\hline Sm & 22.2 & 23.1 & 7.3 & 5.3 & 8.4 & 4.1 & 36.9 & 13.5 & 18.7 & 2.9 \\
\hline Eu & 0.5 & 0.3 & 0.2 & 0.2 & 0.3 & 0.3 & 0.8 & 0.2 & 0.4 & 0.2 \\
\hline $\mathrm{Gd}$ & 23.6 & 18.7 & 7.3 & 6 & 8.9 & 4.8 & 36.1 & 12 & 15.4 & 4.1 \\
\hline $\mathrm{Tb}$ & 9.3 & 7.6 & 3.9 & 2.6 & 4.2 & 2.1 & 16.6 & 5.5 & 6 & 1.7 \\
\hline Dy & 69.9 & 58.2 & 36 & 24.5 & 35 & 18.1 & 134.8 & 45.6 & 46.6 & 14.6 \\
\hline Ho & 17.9 & 14.7 & 9.9 & 7 & 9.5 & 5.4 & 35.4 & 11.9 & 11.6 & 4.3 \\
\hline $\mathrm{Er}$ & 64.2 & 50.6 & 40.5 & 28.7 & 37.1 & 22.2 & 128.6 & 45.2 & 43.2 & 17.1 \\
\hline $\mathrm{Tm}$ & 13.8 & 11.4 & 11.1 & 7.1 & 9.2 & 5.8 & 31.5 & 11.2 & 9.9 & 4 \\
\hline $\mathrm{Yb}$ & 91.1 & 89.2 & 92.8 & 55 & 71 & 44.2 & 231.9 & 80.5 & 73 & 29.6 \\
\hline Lu & 14.2 & 14.4 & 15.8 & 9 & 11 & 7.5 & 35.8 & 14.3 & 11.2 & 5.2 \\
\hline REEs & 506.54 & 629.67 & 444.67 & 226.71 & 321.19 & 186.95 & 1043.12 & 485.36 & 509.83 & 140.96 \\
\hline$\Sigma$ LREEs & 202.04 & 364.57 & 227.17 & 86.61 & 134.99 & 76.55 & 391.62 & 258.96 & 292.53 & 60.16 \\
\hline$\sum$ HREEs & 304.5 & 265.1 & 217.5 & 140.1 & 186.2 & 110.4 & 651.5 & 226.4 & 217.3 & 80.8 \\
\hline $\mathrm{L} / \mathrm{H}$ & 0.66 & 1.38 & 1.04 & 0.62 & 0.72 & 0.69 & 0.60 & 1.14 & 1.35 & 0.74 \\
\hline $\mathrm{Eu} / \mathrm{Eu}^{*}$ & 0.07 & 0.04 & 0.08 & 0.11 & 0.11 & 0.21 & 0.07 & 0.05 & 0.07 & 0.18 \\
\hline $\mathrm{Eu} / \mathrm{Sm}$ & 0.023 & 0.013 & 0.027 & 0.038 & 0.036 & 0.073 & 0.022 & 0.015 & 0.021 & 0.069 \\
\hline $\mathrm{TE}_{1,3}$ & 1.443 & 1.69 & 1.92 & 1.7 & 1.72 & 1.55 & 1.64 & 1.86 & 1.62 & 1.47 \\
\hline
\end{tabular}

Normalized REEs after Boynton [8]. Eu/Eu* $=\mathrm{Eu}_{\mathrm{N}} /\left[\left(\mathrm{Sm}_{\mathrm{N}}\right) \cdot\left(\mathrm{Gd}_{\mathrm{N}}\right)\right]^{0.5}$ according to Taylor and McLennan [60]
The studied pegmatites have moderate to high concentration of $\mathrm{U}, \mathrm{Th}, \mathrm{Li}, \mathrm{Nb}$, $\mathrm{Ta}$ ( $\mathrm{Nb}$ ' $\mathrm{Ta}$ ), Zr, Ga, Pb, Zn, Y, Be. From the previous data, the studied pegmatites can be classified as a Niobium-Yttrium-Fluorine (NYF) pegmatite or rare metal pegmatite (Fig. $6 \mathrm{~b}$ ). The $\mathrm{Nb} / \mathrm{Ta}$ ratio in the studied pegmatites ranges from 6.85 to 10.03 , which refers to the decisive increase in the Ta due to effect of hydrothermal solution. Magmatic rocks of continental crust origin generally have low $\mathrm{Nb} / \mathrm{Ta}$ ratio (11-12) [64]. The $\mathrm{Zr} / \mathrm{Hf}$ ratio ranges from 13.18 to 17.93 , suggesting significant change in the crystal chemistry of zircon toward increasing contents of $\mathrm{Hf}$. The Th/U ratio ranges from 0.42 to 34.87 and $\mathrm{K} / \mathrm{Rb}$ ratio ranges from 53.19 to 105.36 , indicating a wide range of variation due to the leaching of uranium and accordingly enrichment in thorium as well as potassium. Bau et al. [6] suggest the complexation with fluorine as major cause for $\mathrm{Y} / \mathrm{Ho}$ values $>28$, while the complexing with bicarbonate is assumed to generate values $<28$. The $\mathrm{Y} / \mathrm{Ho}$ ratio in the studied granitic pegmatite ranges from 17.93 to 22.76 , suggesting complexing with bicarbonate.

The plotting $\mathrm{K} / \mathrm{Rb}$ ratio vs. Cs, the studied pegmatite samples fall in barren field and muscovite class according to Cerny and Burt [11], due to the depletion of Cs content (Fig. 5a). Ta vs. Ga and Ta vs. K/Cs plots (Fig. $5 \mathrm{~b}$ and c) reveal that nearly all samples have high level of rare elements mineralization, based on the line of mineralization proposed by Beus [7] and a little of them above base line of mineralization proposed by Gordiyenko [25]. Ta vs. Cs + Rb plots also reveal a moderate to high level of rare element mineralization (Fig. $5 \mathrm{~d}$ ), based on the line of mineralization proposed by Beus [7] and Gordiyenko [25].

The plots of $\mathrm{Na}_{2} \mathrm{O}$ against $\mathrm{K} / \mathrm{Cs}$ ratio (Fig. 6a) reveal that all the pegmatite samples fall in $\mathrm{Li}$-bearing pegmatite field (1b) according to Gordiyenko [25] except one sample fall on mica field. The plots of $\mathrm{Li}$ against $\mathrm{K} / \mathrm{Rb}$ ratio (Fig. $6 \mathrm{~b}$ ) reveal that samples spread in muscovite class pegmatite and in rare element class pegmatite.

The $\mathrm{SiO}_{2}$ (wt\%) form positive correlation with $\mathrm{U}(\mathrm{ppm})$ and negative correlation with $\mathrm{Th}(\mathrm{ppm})$, whereas $\mathrm{Th} / \mathrm{U}$ ratio form negative correlation with $\mathrm{Zr}$ and $\mathrm{Hf}$. This indicates that the increase in uranium is directly proportional with $\mathrm{SiO}_{2}, \mathrm{Zr}$ and $\mathrm{Hf}$ (Fig. $7 \mathrm{a}-\mathrm{d}$ ).

\subsection{Rare earth elements}

REEs analyses of Represented samples of pegmatites are listed in Table 3. The total REEs ranging from 140.96 to $629.67 \mathrm{ppm}$, where LLREEs range from 60.16 to $364.57 \mathrm{ppm}$ and $\sum$ HREEs range from 80.8 to $304.5 \mathrm{ppm}$. The high content of REEs in sample no. GP7 is due to the enrichment by xenotime and monazite minerals. The studied pegmatites reveal a small negative Eu anomaly (Eu/ 
$\mathrm{Eu}^{*}=0.04$ to 0.21 ) pattern. It has an average $\mathrm{Eu} / \mathrm{Sm}=0.034$ and LREEs/ HREEs $=0.9$.

Chondrite-normalized REEs patterns (Fig. 8a), of the studied pegmatites are characterized by strong ( $\Sigma$ LREEs) $\mathrm{n}$ and ( $\Sigma$ HREEs) $\mathrm{n}$ enrichment due to the presence of some accessory minerals-bearing REEs, e.g., monazite, xenotime, and zircon. The pattern denotes moderate REEs fractionation in both LREES and HREEs with positive Ce anomaly. The tetrad effect has been progressively recognized particularly for the granitic rocks which have undergone a high degree of fractional crystallization, hydrothermal alteration, and mineralization [5, 30, 32, 37, 66]. Masuda et al. [44] classified the tetrad effects into two different types, $M$ and $W$-type (M-type in solid sample as residues and W-type in the interacting fluids as extract). The tetrad effect in the studied pegmatites was calculated according to Irber Eqs. (1999):

$$
\begin{gathered}
t_{1}=\left(\mathrm{Ce} / \mathrm{Ce}^{t} x \operatorname{Pr} /{ }^{t} \mathrm{Pr}\right)^{0.5}, t_{3}=\left(\mathrm{Tb} / \mathrm{Tb}^{t} x \mathrm{Dy} / \mathrm{Dy}^{t}\right)^{0.5} \\
\quad \text { and } T_{1,3}=\left(t_{1} x t_{3}\right)^{0.5}, \text { when } \mathrm{TE}_{1,3}
\end{gathered}
$$

The studied rock have $\mathrm{TE}_{1,3}$ values (1.44-1.92) more than 1.1, so they show tetrad effect (Table 3). The fractionation of elements with similar ionic radius and charge is regarded to be sensitive to change in the melt composition during magma differentiation $[5,31]$.

Spider diagram of normalized element data of average pegmatites concentration relative to average continental crust by Weaver and Tarney [65] is shown as in Fig. 8b.

It can be observed that, the elements have four behaviors; the first is strong enrichment (Rb, Th, $\mathrm{U}, \mathrm{Nb}, \mathrm{Hf}, \mathrm{Tb}, \mathrm{Y}$, $\mathrm{Tm}$ and $\mathrm{Yb}$ which is a characteristic of dominated crustal material in the parent magma [51]. The second is slight enrichment ( $\mathrm{K}$ and $\mathrm{Zr}$ ). The third behavior is depletion ( $\mathrm{Ba}$, $\mathrm{Sr}, \mathrm{P}$ and $\mathrm{Ti}$ ) and the fourth is the distribution of the elements around up/down the unity ( $\mathrm{La}, \mathrm{Ce}, \mathrm{Nd}$ and $\mathrm{Sm}$ ).

\subsection{Spectrometric investigation}

Uranium mobilization (eUm) in the studied rock types can be calculated as follows: the uranium mobilization is calculated by the difference between the measured eU and the expected original uranium, which is calculated by dividing the measured eTh by the average eTh/eU ratio in the crustal acidic rocks (original uranium $=e T h / 3.5$ according to [17] to give the leaching values of uranium (eUm $=\mathrm{eU}-\mathrm{eTh} / 3.5)$. The result of the uranium mobilization equation $(\mathrm{eUm}=\mathrm{eU}-\mathrm{eTh} / 3.5)$ is the hypothetical uranium distribution [10]. It is helpful in defining the trends of uranium migration. Positive values indicate uranium addition by mobilization, whereas negative values indicated migration of uranium by leaching.

\subsection{Monzogranite radiometric investigation}

The D.R., K\%, eU, eTh and eUm values in the monzogranites are illustrated in Table 4. The average eU content in the monzogranites (4.71 ppm) is less than twice their Clark value (4 ppm), this indicates that the eU in monzogranites are agreed with the average content of the crust and this monzogranites are not uraniferous.

The binary relations of D.R. versus, eU and eTh, are illustrated in Fig. 9a, b. They show positive relation. The plot of $\mathrm{eU}$ versus eTh illustrates that there are positive relations $(r=0.51)$ between the variants indicating their magmatic origin (Fig. 9c). Weak negative relation $(r=-0.03)$ exist between eTh and eTh/eU (Fig. 9d). Strong negative relation ( $r=0.85$ ) exist between $U$ vs. eTh/eU ratio (Fig. 9e). The migration equation for the studied monzogranites indicates uranium leached from parts and added in another parts (Fig. 9f).

\subsection{Pegmatites radiometric investigation}

The radioactive anomaly in the study area is confined to the pegmatites. The D.R. content ranges between 456.4 and $942 \mathrm{nSvh}^{-1}$ with an average of $699.17 \mathrm{nSvh}^{-1}$, whereas the average (eTh/eU) ratio is $0.98 \mathrm{ppm}$ (Table 5, Fig. 10). The eU content ranges between 39 and 96.2 ppm with an average of $65.16 \mathrm{ppm}$, and the eTh content ranges between 41.2 and 83 ppm with an average of $61.66 \mathrm{ppm}$.

The binary relations of D.R., eU, eTh, and eTh/eU are illustrated in Fig. 10. These relations may provide an indicator of the geochemical behavior of $U$ and $T h$ in the studied pegmatites. Strong positive relations exist between D.R. and eU $(r=0.98)$ and also with eTh $(r=0.98)$ (Fig. 10a, b). The plot of eU versus eTh illustrates that there are very strong positive relations $(r=0.97)$ between the variants indicating their magmatic origin (Fig. 10c). Strong negative relation ( $r=0.85$ ) between eU versus eTh/eU, while weak negative relation $(r=-0.03)$ exist between eTh and eTh/eU as shown in Fig. 10d, e). Result of the equation $\mathrm{eU}-(\mathrm{eTh} / 3.5)$ revealed that some of the measurements lie under the zero line, and this means that these samples have been originated from a late magmatic phase of magma very rich in radioelements with thorium concentration more than uranium. On the other side, the majority of measurements lie above the zero line indicating that the pegmatites affected with hydrothermal solutions rich in uranium than thorium which indicates uranium addition (Fig. 10f). 

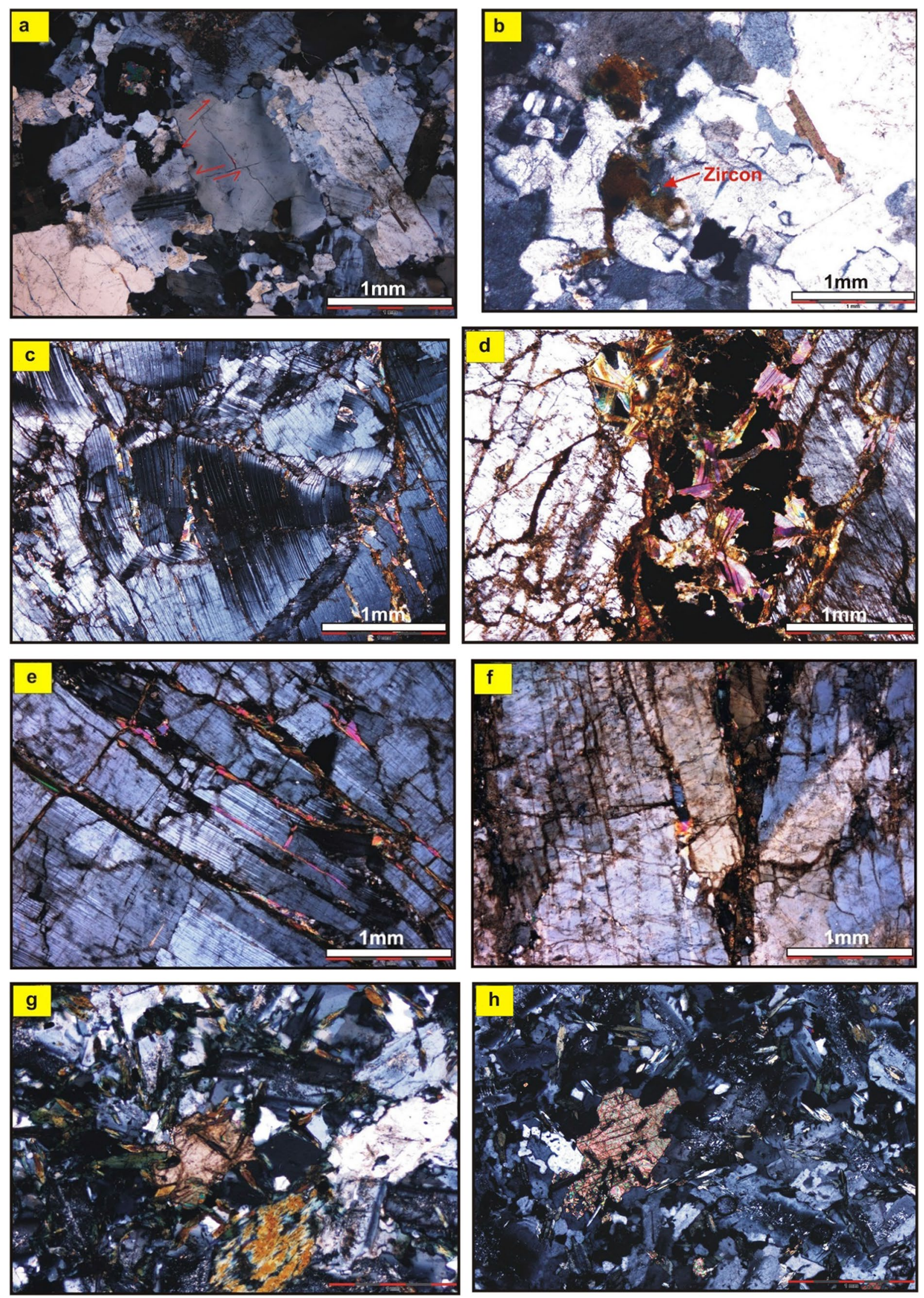
4Fig. 3 Photomicrograph of monzogranites showing; a Quartz crystal affected by ductile and brittle deformation with displacement as strike slip faults, Crossed Nicols (C.N.), b Zircon crystal enclosed within biotite and feldspars,; c Plagioclase crystal form twins and has two or more parts is differently orientated due to strain effect, (C.N.) d Fan-shape muscovite, e elongated muscovite filling fractures of plagioclase and associated with opaques, (C.N.) and $\mathbf{f}$ Opaques filling fractures, (C.N.).; $\mathbf{g}$ and $\mathbf{h}$ Partiality to completely alteration of plagioclase to saussrite and pyroxene to actinolite and also alteration of hornblende to chlorite, (C.N.)

\subsection{Mineralogical investigations}

The mineralogical study aim to detect the radioactive minerals within studied pegmatites, which shows that the most common radioactive and important minerals of the studied pegmatites are represented by uranothorite, columbite, zircon, monazite, xenotime, sphalerite and pyrite. The morphological features and their percentage contents are attached for each mineral (Figs. 11, 12, 13, $14,15,16$ and 17.

\subsection{Uranothorite $\left[(\mathrm{Th}, \mathrm{U}) \mathrm{SiO}_{4}\right]$}

It is usually metamict and contains REEs in a few percent with Ce earths usually dominant and contains uranium and yttrium. EDX techniques revealed that it contains 49.48\% Th, 29.62\% U, 18.96\% Si and 1.94\% Al (Fig. 11).

\subsection{Columbite $(\mathrm{Fe}, \mathrm{Mn})(\mathrm{Nb}, \mathrm{Ta})_{2} \mathrm{O}_{6}$}

It occurs as well-developed orthorhombic crystals in pegmatite exhibiting black color and shiny luster. Columbite is always associated with tantalite because $\mathrm{Nb}^{+5}$ and $\mathrm{Ta}^{+5}$ are closely associated and are always found together. Heinrich [26] concluded that some columbite might be radioactive because of the presence of uranium and thorium in its structure, or from inclusion, veinlets, or coatings of strongly radioactive minerals. Tischendorf [61] concluded that columbite-tantalite mineralization is genetically associated with post-orogenic geochemically distinct granitoids. EDX analysis of selected crystals from the pegmatites revealed that they have $21.79 \% \mathrm{Nb}, 23.09 \%$ $\mathrm{Ti}, 15.75 \% \mathrm{U}, 15.29 \% \mathrm{Y}, 6.49 \% \mathrm{~Pb}, 4.83 \% \mathrm{Fe}, 4.22 \% \mathrm{Si}$ and 2.47\% Ta (Fig. 12).

\subsection{Zircon $\left[\mathrm{ZrSiO}_{4}\right]$}

It occurs as euhedral six-sided or eight-sided form with clusters of opaque inclusions. It is mainly colorless to pale yellow color. Rankama and Sahama [52] stated that thorite is isomorphic with zircon and it is evident that a large part of thorium is incorporated in the zircon structure. The ionic size of zirconium and thorium are not too unlike and therefore thorium is able to enter the zircon structure in which it replaces. EDX analysis for separated mineral grains of pegmatite proved that they comprise $\mathrm{Zr}, \mathrm{Si}, \mathrm{Hf}, \mathrm{Ti}, \mathrm{U}$ and Th (Fig. 13).

\subsection{Monazite $\left[(\mathrm{Ce}, \mathrm{REE}) \mathrm{PO}_{4}\right]$}

It occurs as very fine subhedral to anhedral grains in pegmatite samples. It exhibits transparent lemon yellow, honey yellow and reddish yellow with resinous luster. Monazite have a wide range of $L R E E$ and is iso-structural with cheralite $(\mathrm{RE}, \mathrm{Th}, \mathrm{Ca}, \mathrm{U})(\mathrm{P}, \mathrm{Si}) \mathrm{O}_{4}$ and with huttonite $\left(\mathrm{ThSiO}_{4}\right)$, both of which have highly cerium REE distributions $[9,49]$. Thorium is usually existing in monazite in substitution for the REE. Jensen [34] concluded that the monazite structure would accept REE ions with ionic radii between those of $L a$ and $E u$. It is confirmed by SEM-EDX technique and contains $\mathrm{Ce}$, La, $\mathrm{P}, \mathrm{Nd}, \mathrm{Pr}, \mathrm{U}$ and Th (Fig. 14).

\subsection{Xenotime $\left[\mathrm{YPO}_{4}\right]$}

It exhibits translucent yellowish red to reddish brown colors with resinous luster. It is a tetragonal mineral iso-structural with zircon, $\mathrm{ZrSiO}_{4}$. Besides $\mathrm{Y}$, other rare earth elements (REE), predominantly heavy rare earth elements (HREE), and the actinide elements $U$ and $T h$, are incorporated preferentially at the eight-fold lattice site in the xenotime-( $\mathrm{Y})$ structure [47, 63]. It is confirmed by SEM-EDX technique and contains $Y, P$, Yb, Er and Si (Fig. 15).

\subsection{Sphalerite $[(\mathrm{Zn}, \mathrm{Fe}) \mathrm{S}]$}

It is commonly associated with other sulfide minerals, such as galena and pyrite. It is confirmed by SEM-EDX technique and contains $\mathrm{Zn}, \mathrm{S}$ and Fe (Fig. 16).

\subsection{Pyrite $\left[\mathrm{FeS}_{2}\right]$}

It occurs as cubes, octahedral showing a brown color with metallic luster. The oxidized form of pyrite is unstable and decomposed into insoluble iron hydroxide and free sulfuric acid which passes into solution. It is confirmed by SEM-EDX analysis for separated mineral grains of pegmatite and contains Fe and S (Fig. 17).

\section{Discussion}

Many rare metals used today are derived from granitic pegmatites, but debate continues about the origin of these rocks. Since the studied pegmatites have classified as a Niobium-Yttrium-Fluorine (NYF) pegmatite or rare metal pegmatite. The following discussion aims to 

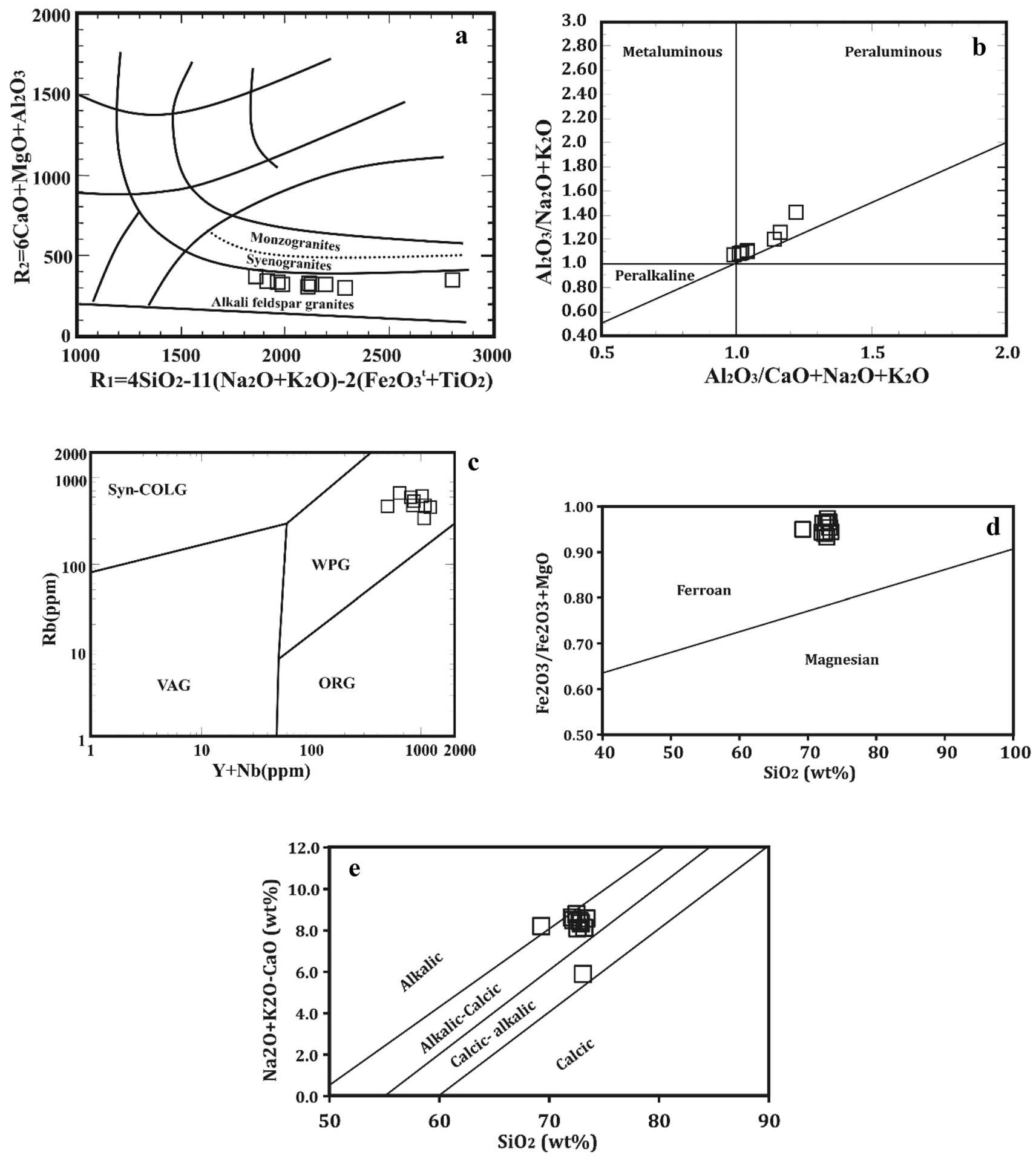

Fig. 4 a R1-R2 diagram for the pegmatites of W. Ghadir, SED, Egypt, after De La Roch et al. [18]. b Shand's index diagram for the pegmatites of W. Ghadir, SED, Egypt, after Clarke [16] .c Rb vs. $\mathrm{Y}+\mathrm{Nb}$ diagram for the pegmatites of W. Ghadir, SED, Egypt, [51]. d Fig. 4e: $\mathrm{SiO}_{2}$ vs. $\mathrm{Fe}_{2} \mathrm{O}_{3} /\left(\mathrm{Fe}_{2} \mathrm{O}_{3}+\mathrm{MgO}\right)$ diagram showing the bound- ary between ferroan and magnesian intrusions of the pegmatites of W. Ghadir, SED, Egypt, Frost et al. [22]. e $\mathrm{SiO}_{2}$ vs. $\mathrm{Na}_{2} \mathrm{O}+\mathrm{K}_{2} \mathrm{O}-\mathrm{CaO}$ diagram [22] showing the approximate range for the alkalic, alkalicalcic, calc-alkalic, and calcic series of the pegmatites of W. Ghadir, SED, Egypt 

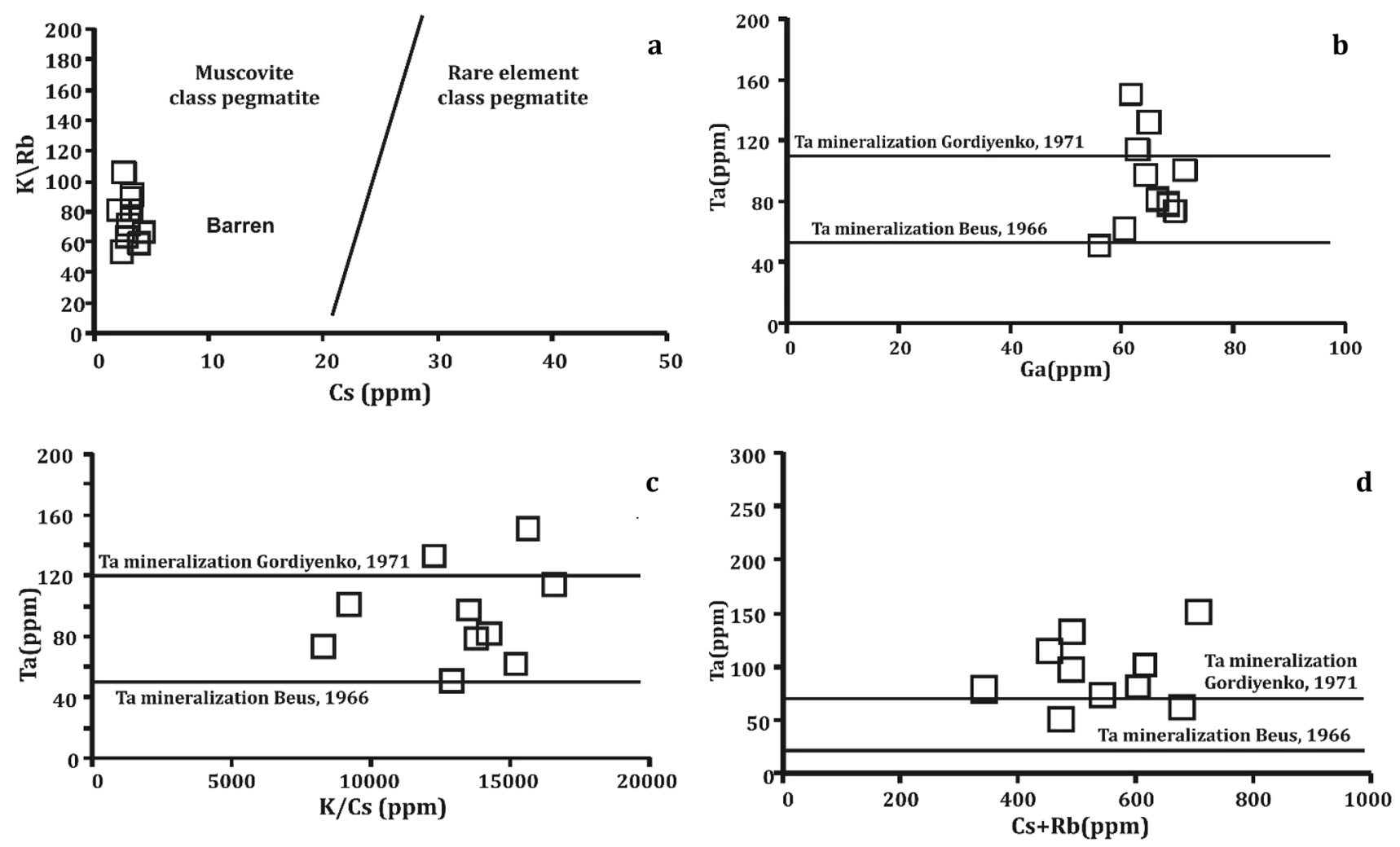

Fig. 5 a Cs vs. K/Rb, b Ga vs. Ta, c K/Cs vs. Ta, d Cs + Rb vs. Ta for the studied granitic pegmatite of W. Ghadir, SED, Egypt. The discrimination lines according to Cerny and Burt [11]
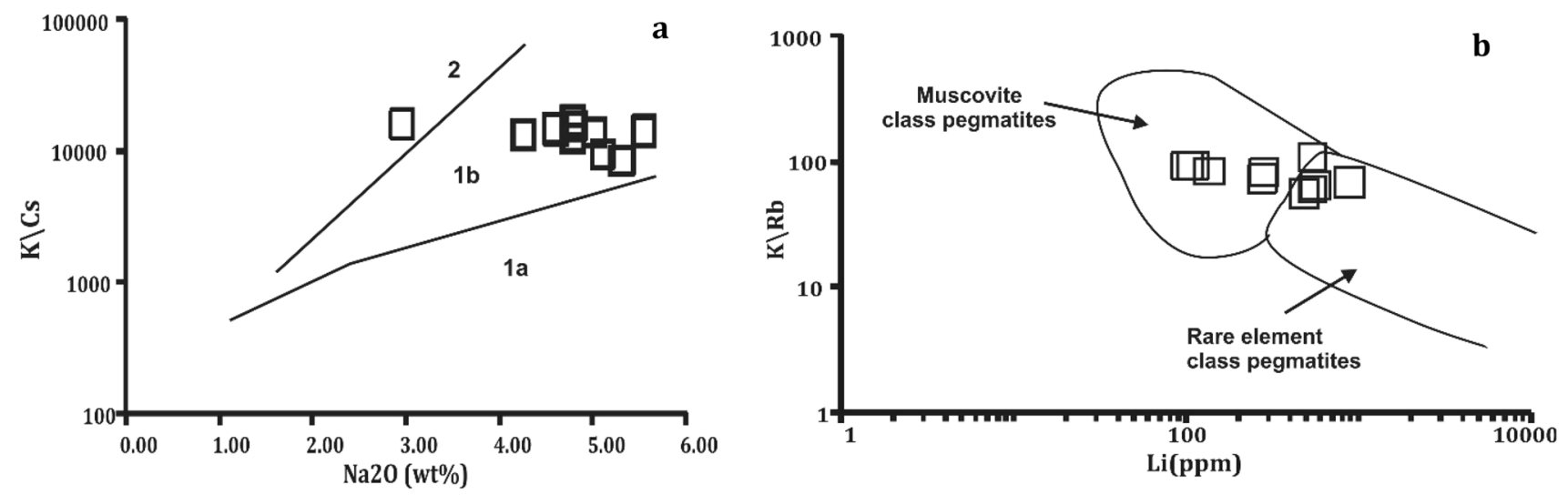

Fig. 6 a $\mathrm{Na}_{2} \mathrm{O}$ vs. $\mathrm{K} / \mathrm{Cs}$ for the studied granitic pegmatite of W. Ghadir, SED, Egypt. $(2=$ mica bearing, $1 \mathrm{a}=\mathrm{Cs}$ bearing and $1 \mathrm{~b}=\mathrm{Li}$ bearing), according to Gordiyenko [25] as presented in Trueman and Cerny [62]

understand the classification and suggested origin of pegmatites. "Cerny and Ercit [13] introduced a revised petrogenetic classification in which three families are distinguished: "an NYF family with progressive accumulation of $\mathrm{Nb}, \mathrm{Y}$ and $\mathrm{F}$ (besides $\mathrm{Be}, \mathrm{REE}, \mathrm{Sc}, \mathrm{Ti}, \mathrm{Zr}$, Th and $U$ ), fractionated from subaluminous to metaluminous A- and I-granites that are generated by a variety of processes involving depleted crust and/or mantle contribution; a peraluminous LCT family marked by prominent accumulation of $\mathrm{Li}, \mathrm{Cs}$ and $\mathrm{Ta}$ (besides $\mathrm{Rb}$, $\mathrm{Be}, \mathrm{Sn}, \mathrm{B}, \mathrm{P}$ and $\mathrm{F}$ ) derived mainly from S-granites, less commonly from I-granites; and a mixed NYF + LCT family of diverse origins (e.g., NYF plutons contaminated by digestion of undepleted supracrustals)". Martin and De Vito [45] contend that the depth zone classification cannot account for the two main geochemical categories of 

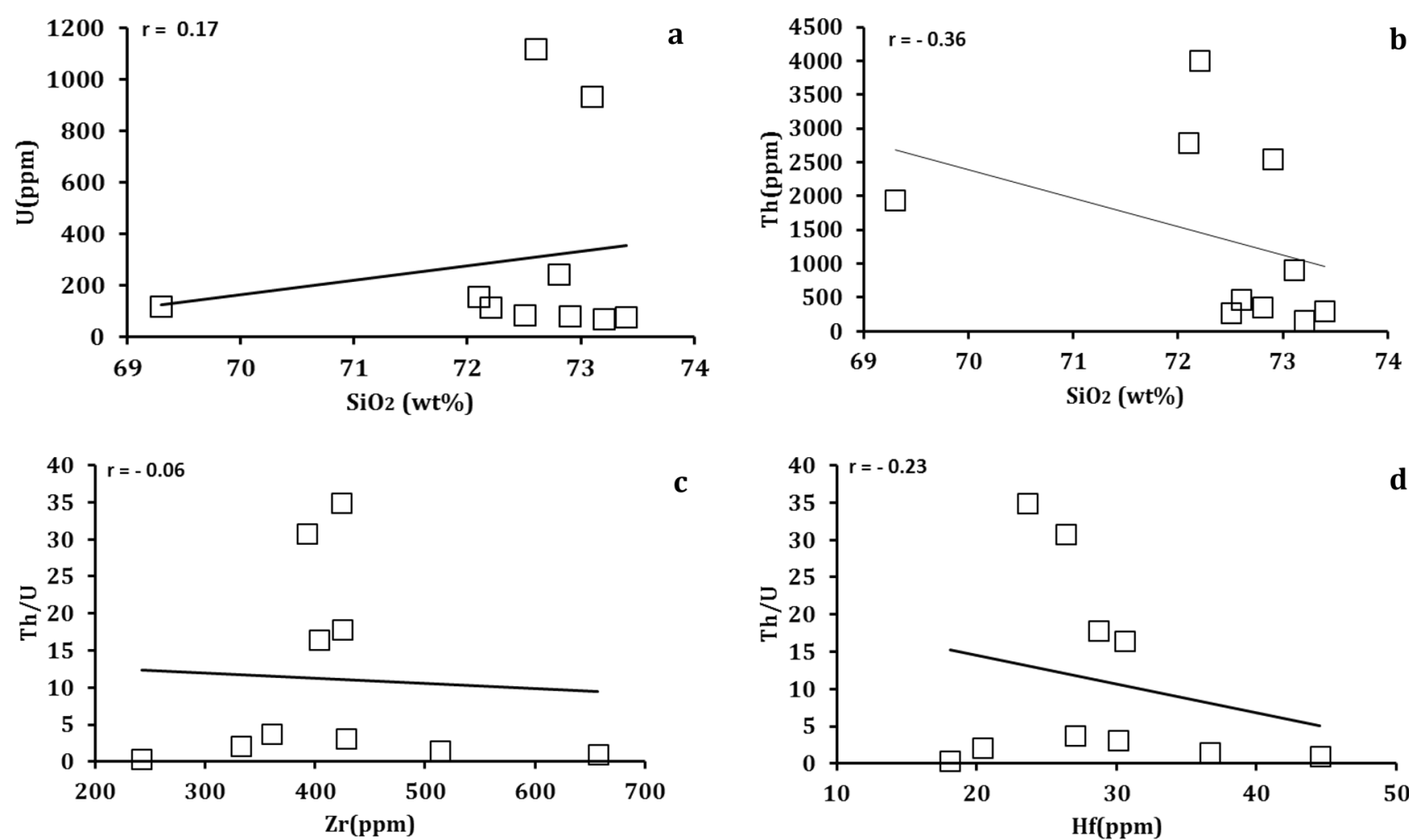

c

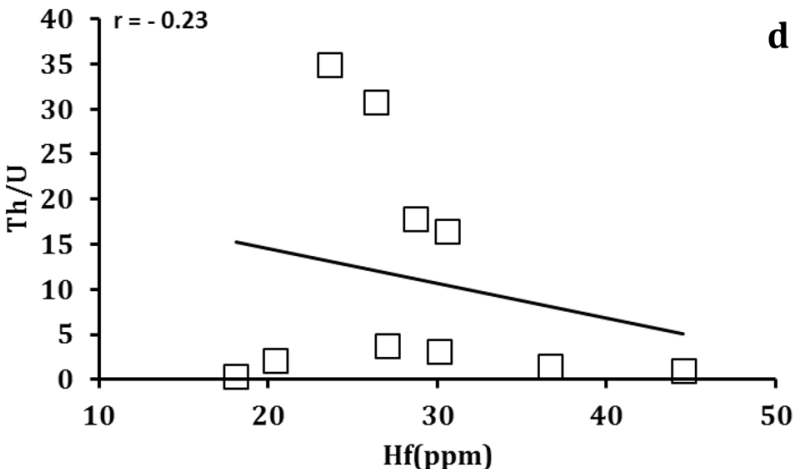

Fig. $7 \mathrm{SiO}_{2}$ (wt\%) vs. a U and $\mathbf{b}$ Th for the studied granitic pegmatite, W. Ghadir, SED, Egypt, Th/U ratio vs. $\mathbf{c}$ Zr and $\mathbf{d}$ Hf for the studied granitic pegmatite, W. Ghadir, SED, Egypt

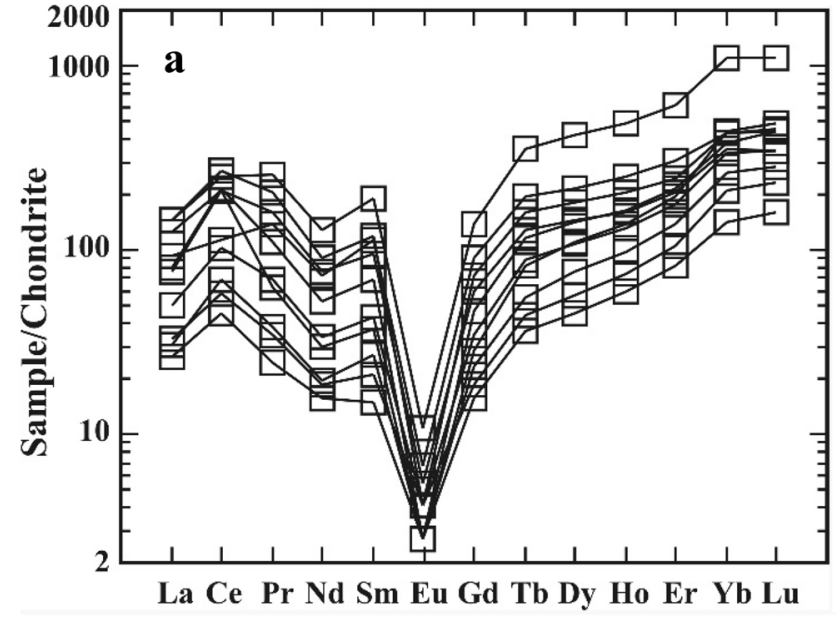

Fig. 8 a Rare earth elements distribution pattern for the pegmatites, W. Ghadir, south Eastern Desert, Egypt. Normalized to Chondrite of Boynton [8], b Spiderdiagram of normalized element data

pegmatites: LCT and NYF. They propose that the tectonic setting determines the nature of the parent magma and the derivative rare-element-enriched magmas. Thus, LCT pegmatites are generated in compressional tectonic

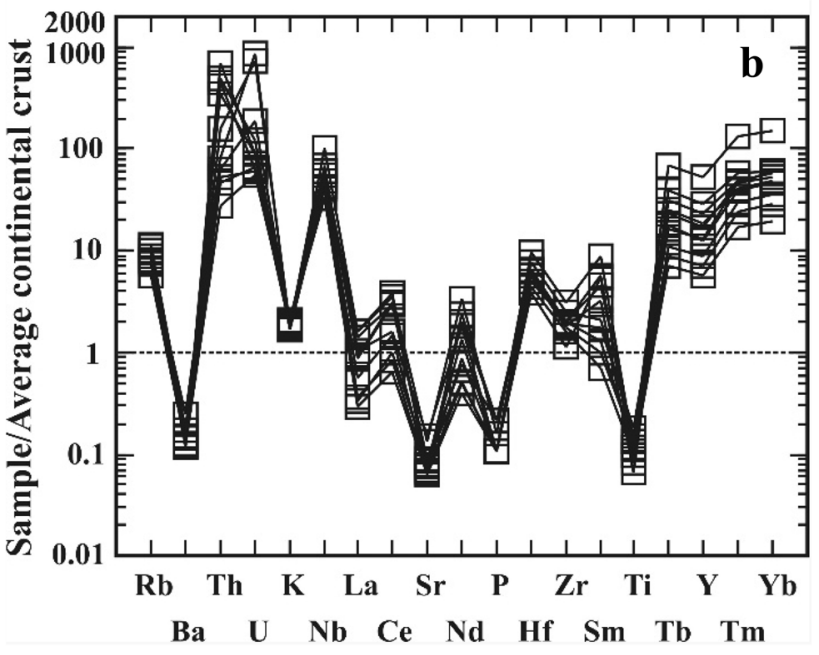

for the pegmatites, W. Ghadir, south Eastern Desert, Egypt. Normalized values refer to average continental crust of Weaver and Tarney [65]

settings (orogenic suites) and NYF from extensional tectonic settings (anorogenic suites). Mixed NYF and LCT are proposed to be the result of contamination, either at the magmatic or postmagmatic stage, in which the evolved 
Table 4 Field radiometric measurements of the monzogranites, Wadi Ghadir area, SED, Egypt

\begin{tabular}{|c|c|c|c|c|c|c|}
\hline Serial no & D.R. (nSvh-1) & $\mathrm{K} \%$ & eU (ppm) & eTh (ppm) & eTh/eU & eUm \\
\hline 1 & 103.9 & 3.1 & 4 & 9 & 2.25 & 1.43 \\
\hline 2 & 114.5 & 4 & 2.4 & 11 & 4.58 & -0.74 \\
\hline 3 & 143.3 & 3.8 & 6.2 & 13 & 2.10 & 2.49 \\
\hline 4 & 118.9 & 4 & 2.6 & 12 & 4.62 & -0.83 \\
\hline 5 & 105.2 & 3.4 & 4.2 & 9.5 & 2.26 & 1.49 \\
\hline 6 & 110.5 & 4.2 & 3.8 & 12.1 & 3.18 & 0.34 \\
\hline 7 & 106.5 & 3.8 & 2.9 & 11 & 3.79 & -0.24 \\
\hline 8 & 112.6 & 4.1 & 3.5 & 11.5 & 3.29 & 0.21 \\
\hline 9 & 115.4 & 4.2 & 4.6 & 11.8 & 2.57 & 1.23 \\
\hline 10 & 117.2 & 3.7 & 5.2 & 10.8 & 2.08 & 2.11 \\
\hline 11 & 129.7 & 3.6 & 5.8 & 11.7 & 2.01 & 2.47 \\
\hline 12 & 142.1 & 3.5 & 6.9 & 13.5 & 1.96 & 3.03 \\
\hline 13 & 107.3 & 3.8 & 4.2 & 8.9 & 2.12 & 1.66 \\
\hline 14 & 145.6 & 4.2 & 7.5 & 13.8 & 1.84 & 3.56 \\
\hline 15 & 110.8 & 4 & 3.6 & 12.8 & 3.56 & -0.06 \\
\hline 16 & 132.3 & 4.2 & 5.8 & 12.6 & 2.17 & 2.20 \\
\hline 17 & 130.2 & 3.8 & 5.5 & 12.2 & 2.22 & 2.01 \\
\hline 18 & 126.5 & 3.5 & 5.2 & 11.2 & 2.15 & 2.00 \\
\hline 19 & 128.5 & 3.6 & 5.6 & 12.1 & 2.16 & 2.14 \\
\hline Min & 103.9 & 3.1 & 2.4 & 8.9 & 1.84 & -0.14 \\
\hline Max & 145.6 & 4.2 & 7.5 & 13.8 & 4.62 & 3.56 \\
\hline Average & 121.11 & 3.82 & 4.71 & 11.61 & 2.68 & 1.39 \\
\hline
\end{tabular}

NYF rocks get "soaked" with a fluid bringing in not only $\mathrm{Li}$ and $\mathrm{B}$, but also $\mathrm{Ca}$ and $\mathrm{Mg}$ from the host rock. They also propose that pegmatites may form by anatexis from both crustal and mantle rocks, which may have been previously metasomatically altered. There are currently two hypotheses that aim to explain how pegmatite-forming melts are generated: (1) extended fractional crystallization of a granitic magma at the scale of a pluton, and (2) direct formation by low-degree partial melting of crustal rocks, typically in the presence of fluids $[40,45]$.In practice, these hypotheses represent two end-members and many pegmatites may be formed by a combination of crustal melting and subsequent fractionation of small magmatic bodies.

It is clear that a trend toward a petrogenetic classification is emerging. We feel that a petrogenetic classification that can relate pegmatites to tectonic regimes and the related magma generating processes is ultimately essential in order to advance our understanding of pegmatite genesis within the larger-scale earth processes. This is an area for much needed future research.

\section{Conclusions}

The studied area is covered by quartz-diorites, monzogranites and pegmatites. The monzogranites are medium to coarse grained with a pinkish color forming medium relief mountain terrains. They attain cavernous weathering, exfoliation, joints, and fractures and also dissected by basic dykes. The pegmatites occur as zoned pockets within monzogranites with gradational contacts and dissected by basic dykes. The pegmatite pockets have the following zonal arrangement: border, wall, intermediate, and core zones. The wall zone have enrichment of radioactive and RREs-bearing minerals.

Geochemically, the pegmatites of W. Ghadir have peraluminous character, ferroan with alkalic-calcic affinity and emplaced in within plate setting. The pegmatites indicate a narrow range of variation between $\mathrm{Nb} / \mathrm{Ta}$, $\mathrm{Zr} / \mathrm{Hf}$ ratios, while it shows a wide range of variation in $\mathrm{Th} / \mathrm{U}, \mathrm{K} / \mathrm{Rb}$ ratios. These pegmatites revealed high level of rare earth elements mineralization. The pegmatites of W. Ghadir are Li-bearing pegmatite. The binary variation 

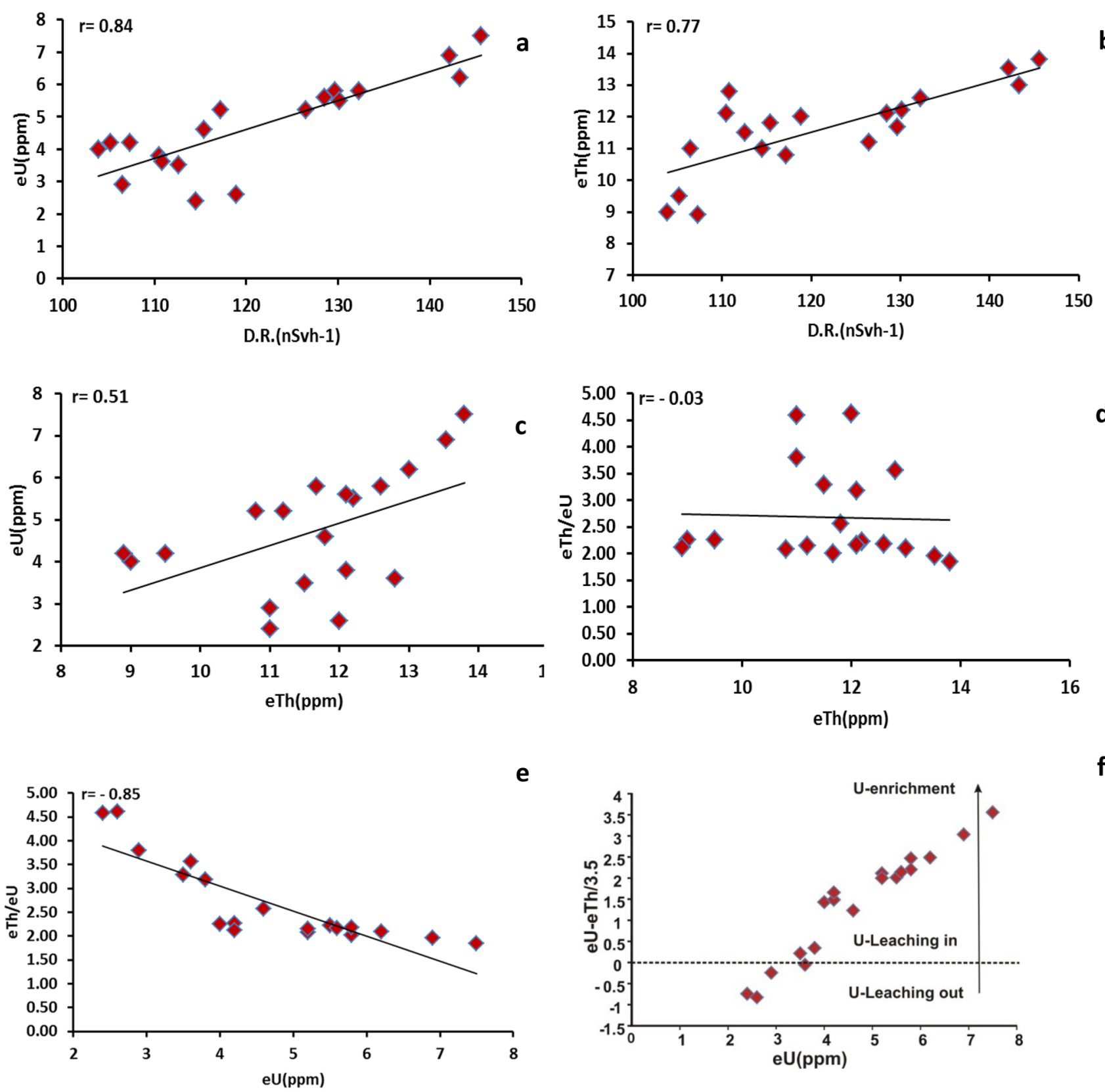

Fig. 9 D.R. versus a K\%, b eU, c eTh, $\mathbf{d}$ eTh versus eU, e eTh versus eTh/eU, $\mathbf{f}$ eU versus eU-eTh/3.5 for the studied monzogranites, W. Ghadir, SED, Egypt

diagrams between $\mathrm{SiO}_{2}(w t \%), \mathrm{U}$, Th and $\mathrm{Th} / \mathrm{U}$ ratio indicates the increase in uranium directly proportional with $\mathrm{SiO}_{2}, \mathrm{Zr}$ and $\mathrm{Hf}$. The major oxides composition ( $\mathrm{MnO}$, $\mathrm{MgO}, \mathrm{CaO}, \mathrm{Na}_{2} \mathrm{O}, \mathrm{TiO}_{2}$, and $\mathrm{P}_{2} \mathrm{O}_{5}$ ) of the pegmatites of W. Ghadir are mostly not different from those of raremetal-bearing pegmatites of Egypt. The trace elements analysis shows that the pegmatites documents relatively medium- to high contents of trace elements and rare metals. The studied pegmatites exhibit high contents of $\mathrm{Li}, \mathrm{Nb}, \mathrm{Cu}, \mathrm{Ta}, \mathrm{U}, \mathrm{Th}, \mathrm{Pb}, \mathrm{Zr}, \mathrm{Zn}$ and $\mathrm{Ga}$, which are the major mineralization indices for pegmatites bodies in the Egyptian basements. Thus, the studied pegmatites can be classified as a Niobium-Yttrium-Fluorine (NYF) pegmatite or rare metal pegmatite. The trace elements ratio supports a low degree of fractionation and metasomatism in the evolutionary history of the pegmatites, and the very low Cs values (2.2-4.3 ppm) recorded for the pegmatites indicate paucity of alkali metal fractionation. These features agree with the weak negative $\mathrm{Ce}$ signature and strong negative Eu anomaly REE pattern 
Table 5 Field radiometric measurements of the granitic pegmatites, Wadi Ghadir area, SED, Egypt

\begin{tabular}{lllllll}
\hline Serial no & D.R. (nSvh-1) & K\% & eU (ppm) & eTh (ppm) & eTh/eU & eUm \\
\hline 1 & 942 & 3.9 & 93 & 83 & 0.89 & 69.29 \\
2 & 456.4 & 4 & 40 & 41.2 & 1.03 & 28.23 \\
3 & 459 & 3.2 & 39.3 & 46.1 & 1.17 & 26.13 \\
4 & 937.4 & 3.2 & 96.2 & 78.2 & 0.81 & 73.86 \\
5 & 470 & 4.7 & 39 & 43 & 1.10 & 26.71 \\
6 & 922 & 3.8 & 85 & 77 & 0.91 & 63.00 \\
7 & 875 & 3.9 & 82.5 & 78 & 0.95 & 60.21 \\
8 & 755 & 4.1 & 70.2 & 60.5 & 0.86 & 52.91 \\
9 & 700.5 & 4.1 & 65.6 & 56.2 & 0.86 & 49.54 \\
10 & 520.3 & 4.2 & 42.5 & 47 & 1.11 & 29.07 \\
11 & 590.5 & 4.3 & 45.8 & 50.2 & 1.10 & 31.46 \\
12 & 632.5 & 3.9 & 60.3 & 56.8 & 0.94 & 44.07 \\
13 & 720.3 & 3.8 & 66.8 & 62.5 & 0.94 & 48.94 \\
14 & 825.3 & 3.6 & 88.2 & 75.4 & 0.85 & 66.66 \\
15 & 890.5 & 3.8 & 85.6 & 82.1 & 0.96 & 62.14 \\
16 & 490 & 3.5 & 42.5 & 49.3 & 1.16 & 28.41 \\
Min & 456.4 & 3.2 & 39 & 41.2 & 0.81 & 27.23 \\
Max & 942 & 4.7 & 96.2 & 83 & 1.17 & 72.49 \\
Average & 699.17 & 3.88 & 65.16 & 61.66 & 0.98 & 47.54 \\
\hline
\end{tabular}

exhibited by mostly the bulk rock pegmatites. The overall geochemical signatures of pegmatites of W. Ghadir, generally indicate low fractionation, and medium- to high-level of rare metal mineralization potential, like the rare-metal-bearing pegmatites in the basement complex of Egypt.

Spectrometric investigation using binary diagrams revealed that monzogranites are not uraniferous, while the radioactive anomaly in the study area is confined to the pegmatites. The binary relations of D.R., eU, eTh, and $\mathrm{eTh} / \mathrm{eU}$ in pegmatites show Strong positive relations exist with $U$ and Th indicating their magmatic origin.
Meanwhile, the result of mobilization equation proved that pegmatite samples have been originated from a late magmatic phase of magma very rich in radioelements, also the majority of measurements lie above the zero line indicating that the pegmatites affected with hydrothermal solutions rich in uranium than thorium which indicates uranium addition.

The mineralogical investigation were done on separated heavy minerals shows that the radioactive and important heavy minerals content of the studied pegmatites are represented by uranothorite, columbite, zircon, monazite, xenotime, sphalerite and pyrite. 


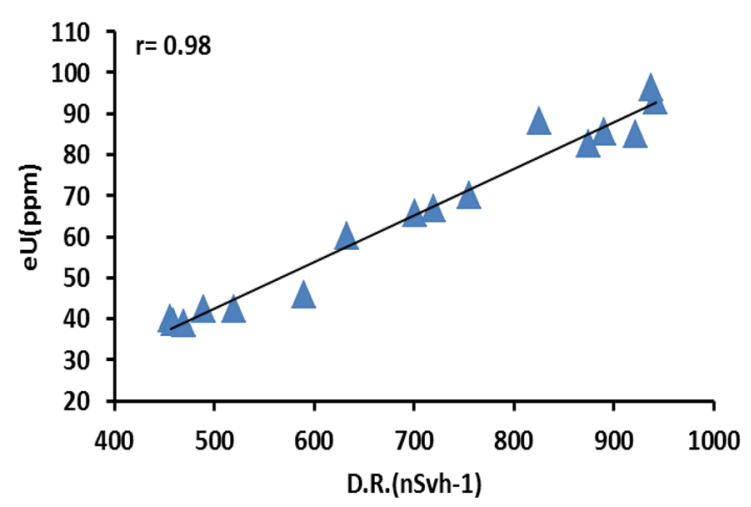

a
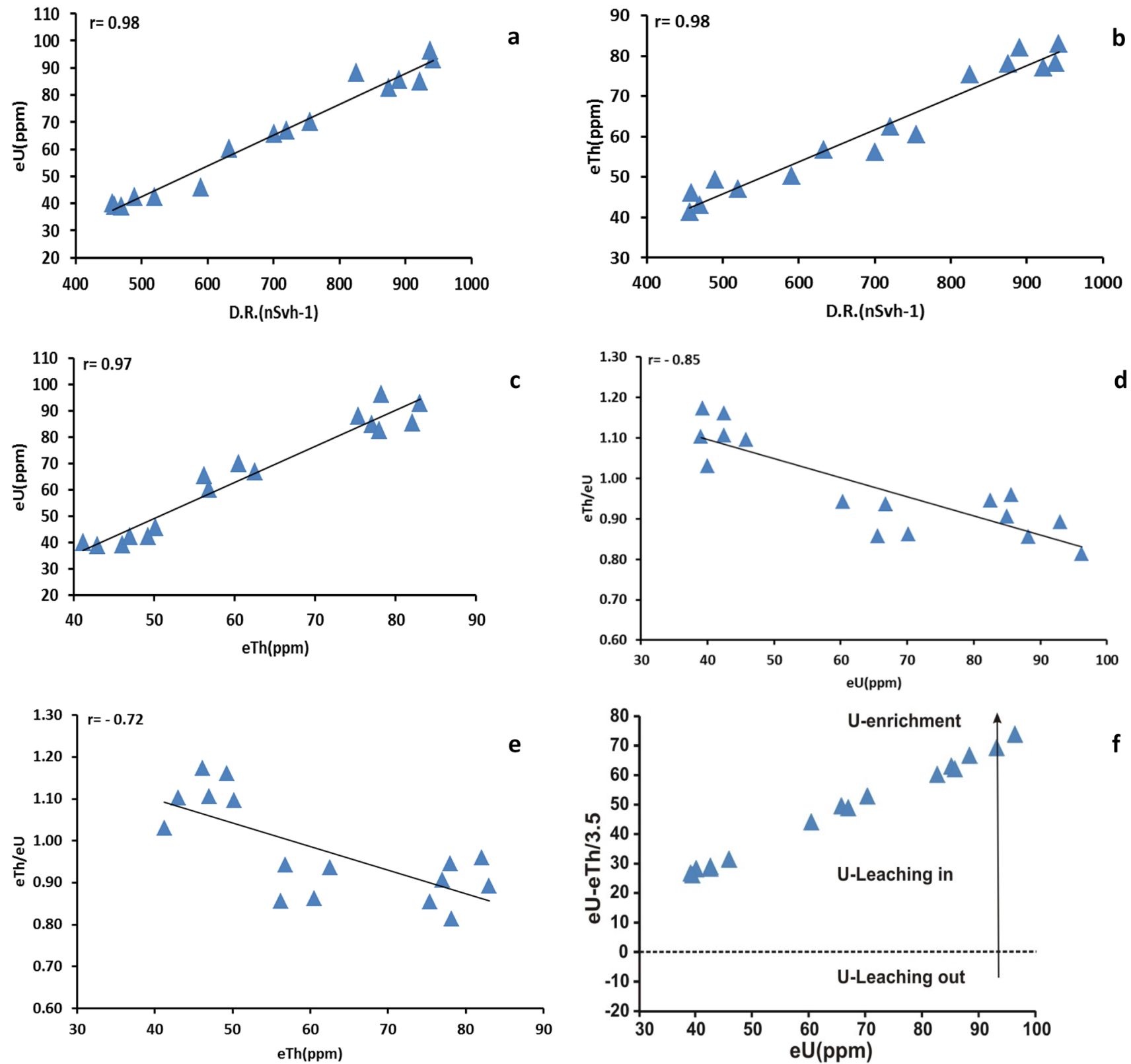

Fig. 10 D.R. versus a K\%, b eU, c eTh, $\mathbf{d}$ eTh versus eU, e eTh versus eTh/eU, $\mathbf{f}$ eU versus eU-eTh/3.5 for the studied granitic pegmatites, W. Ghadir, SED, Egypt 
Fig. 11 SEM image and EDX analysis data of uranothorite mineral for the granitic pegmatites, W. Ghadir, south Eastern Desert, Egypt

Fig. 12 SEM image and EDX analysis data of columbite mineral for the granitic pegmatites, W. Ghadir, south Eastern Desert, Egypt

Fig. 13 SEM image and EDX analysis data of zircon for the granitic pegmatites, W. Ghadir, south Eastern Desert, Egypt

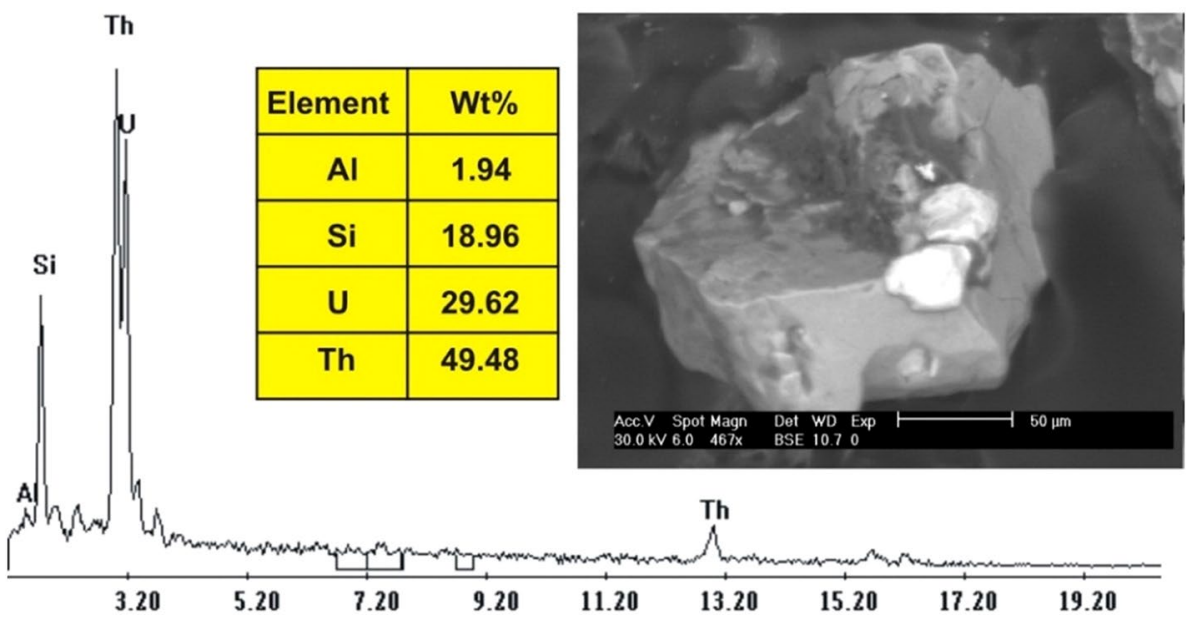

$\mathrm{Ti}$
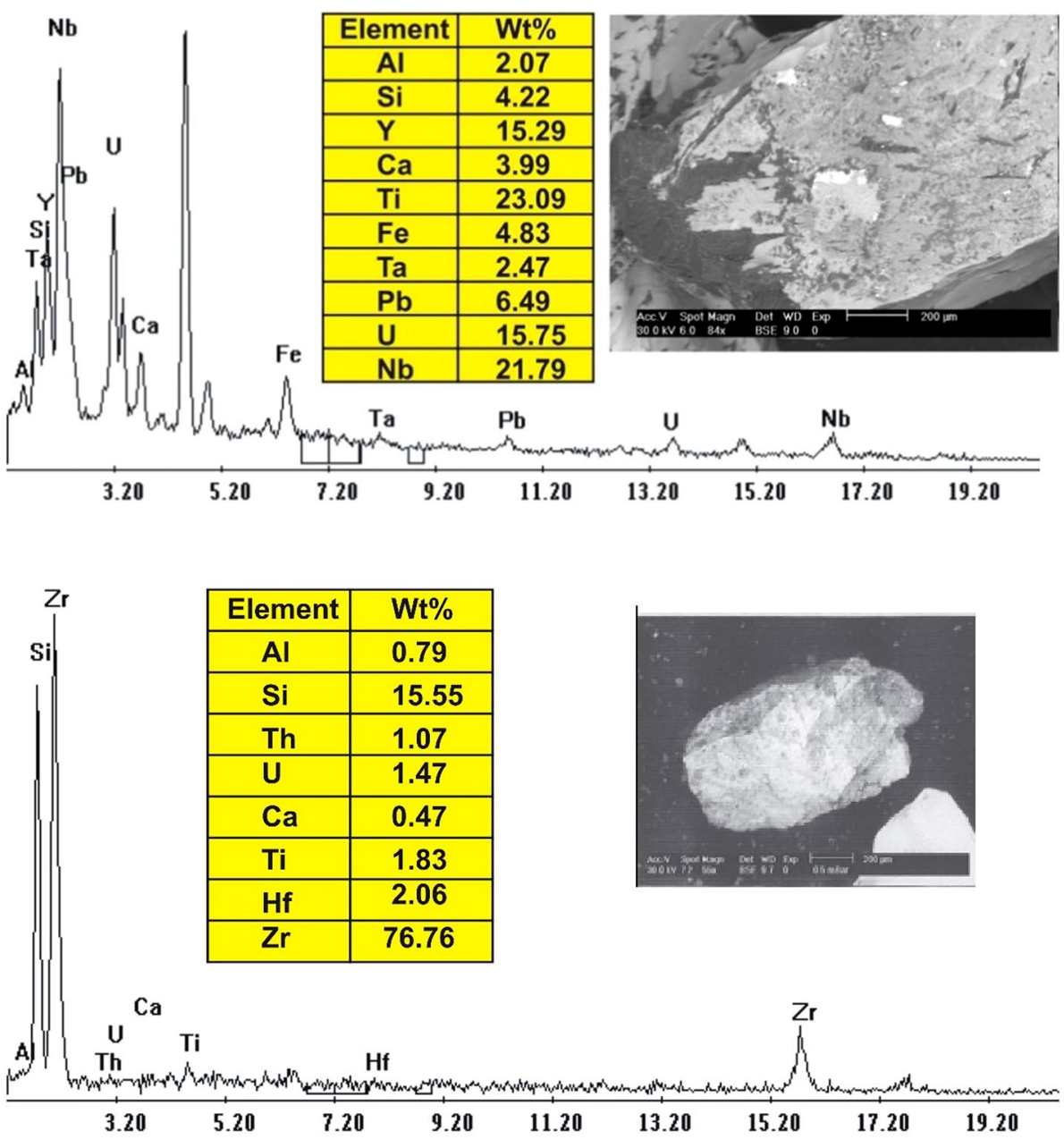
Fig. 14 SEM image and EDX analysis data of monazite for the granitic pegmatites, $W$. Ghadir, south Eastern Desert, Egypt

Fig. 15 SEM image and EDX analysis data of xenotime for the granitic pegmatites, $W$. Ghadir, south Eastern Desert, Egypt

Fig. 16 SEM image and EDX analysis data of sphalerite for the granitic pegmatites, W. Ghadir, south Eastern Desert, Egypt
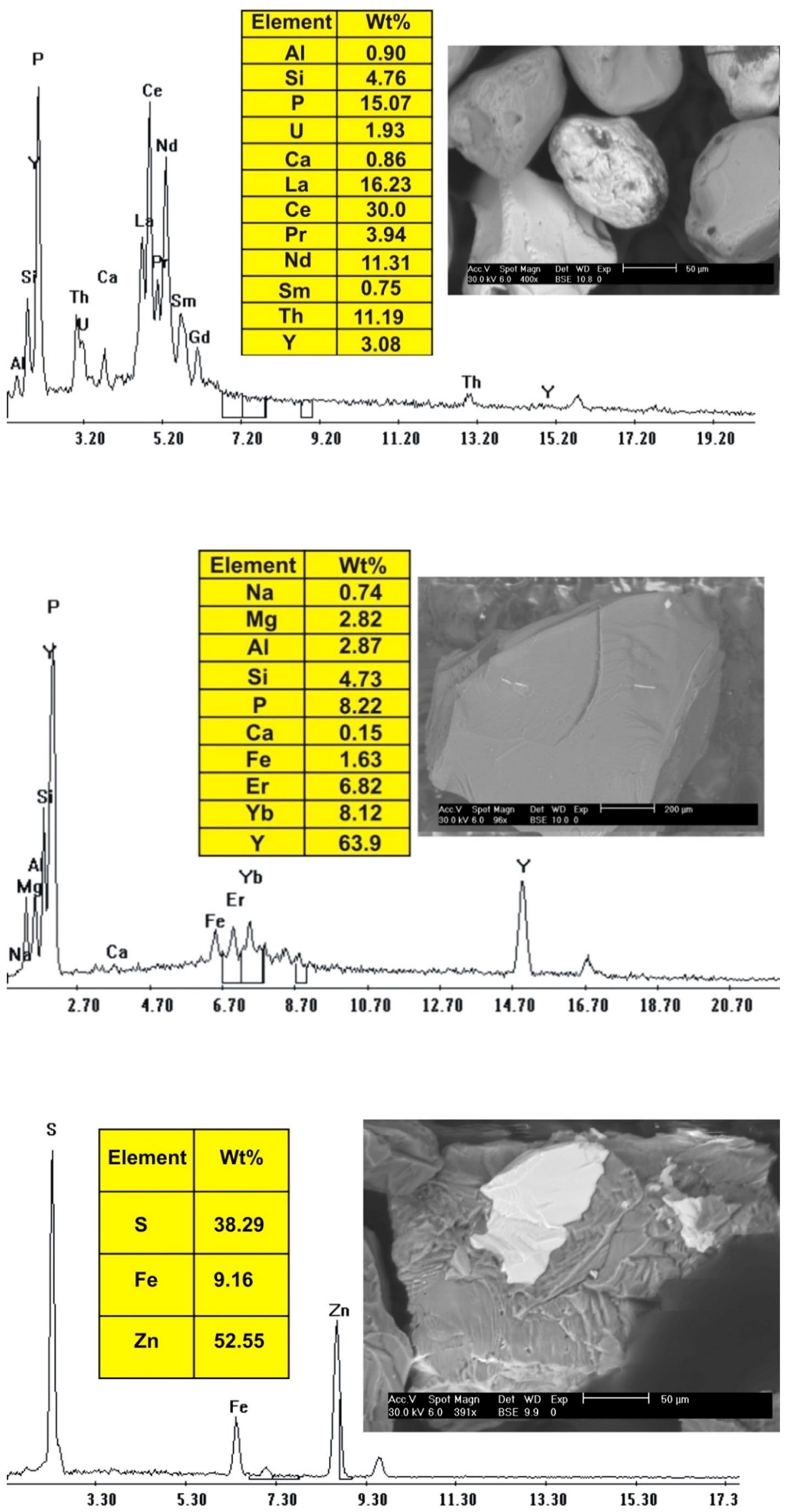
Fig. 17 SEM image and EDX analysis data of pyrite for the granitic pegmatites, W. Ghadir, south Eastern Desert, Egypt

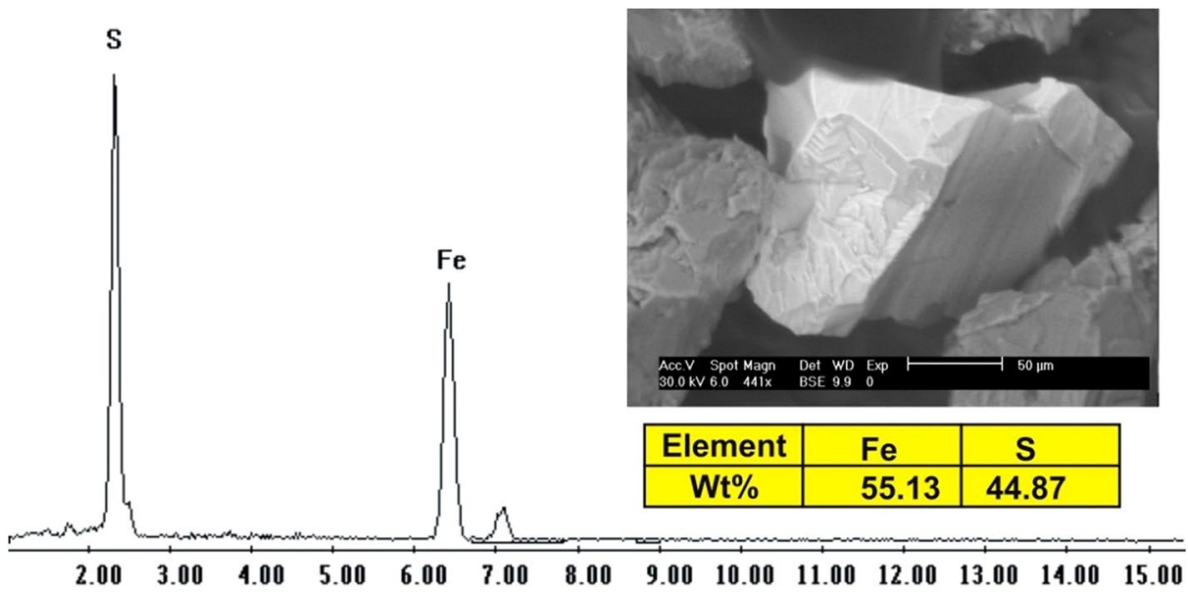

Acknowledgements The authors would like to thanks the colleagues from Abu Rusheid-Halaib project for fieldwork assistance and also thanks Prof. Dr. Mohamed Abu Anbar, Faculty of Science, Tanta University for his helpful comments and suggestions. The authors would like to thank the anonymous reviewers for their comments that help improve this manuscript significantly.

Open Access This article is licensed under a Creative Commons Attribution 4.0 International License, which permits use, sharing, adaptation, distribution and reproduction in any medium or format, as long as you give appropriate credit to the original author(s) and the source, provide a link to the Creative Commons licence, and indicate if changes were made. The images or other third party material in this article are included in the article's Creative Commons licence, unless indicated otherwise in a credit line to the material. If material is not included in the article's Creative Commons licence and your intended use is not permitted by statutory regulation or exceeds the permitted use, you will need to obtain permission directly from the copyright holder. To view a copy of this licence, visit http://creativecommons .org/licenses/by/4.0/.

\section{References}

1. Abdel Warith A, Raslan MF, Ali MA (2007) Mineralogy and radioactivity of pegmatite bodies from the granitic pluton of Gabal Um Tager El-Tahtani Area, Central Eastern Desert, Egypt. The 10th International Mining, Petroleum, and Metallurgical Engineering Conference, Mining, Code No. M3, Faculty of Engineering-Assuit University

2. Ali MA (2001) Geology, petrology and radioactivity of Gabal El-Sibai Area, Central Eastern Desert, Egypt [D]. pp. 300. Ph.D Thesis, Cairo University

3. Ali MA, Raslan MF, El-Feky MG (2005) Radioactivity and mineralogy of some pegmatite bodies from Gabal Al-Farayid Granites, South Eastern Desert, Egypt. The 9th International Mining, Petroleum, and Metallurgical Engineering Conference February 21-24, 2005, Faculty of Engineering-Cairo University

4. Badanina EV, Sitnikova MA, Gordienko VV, Melcher F, Gäbler HE, Lodziak J, Syritso LF (2015) Mineral chemistry of columbite-tantalite from spodumene pegmatites of Kolmozero, Kola Peninsula (Russia). Ore Geol Rev 64:720-735

5. Bau M (1996) Controls on the fractionation of isovalent trace elements in magmatic and aqueous system; evidence from
$\mathrm{Y} / \mathrm{Ho}, \mathrm{Zr} / \mathrm{Hf}$ and lanthanide tetrad effect. Contrib Miner Pet 123:323-333

6. Bau M, Dulski P, Moller P (1995) Yttrium and holmium in South Pacific seawater: Vertical distribution and possible fractionation meachanisms. Chem Erde 55:1-15

7. Beus AA (1966) Distribution of tantalum and niobium in muscovite from granitic pegmatites. Geokhimiya 10:1216-1220

8. Boynton WV (1984) Geochemistry of the rare earth elements: meteorite studies. In: Henderson P (ed) Rare earth element geochemistry. Elsevier, pp 63-114

9. Bowles JFW, Jobbins EA, Young BR (1980) A re-examination of cheralite. Miner Mag 43:885-888

10. Cambon AH (1994) Uranium deposits in granitic rocks. In Notes on the National Training Course on Uranium Geology and Exploration, IAEA and NMA, 8-20, Jan. 1994, Cairo, Egypt

11. Černý P, Burt M (1984) Paragenesis, Crystallochemical Characteristics and Geochemical Evolution of Micas in Granitic Pegmatites. In: Bailly SW (ed) Micas, Reviews in Mineralogy, 13. Mineralogical Society of America, USA, pp 257-297

12. Černý P, Ercit TS (1989) Mineralogy of niobium and tantalum Crystal chemical relationships paragenetic aspects and their economic implications Lanthanides Tantalum and Niobium. In: Cerný P, Saupé F (eds) Möller P. Springer, Berlin

13. Černý $P$, Ercit TS (2005) The classification of granitic pegmatites revisited. Canad Miner 43:2005-2026

14. Černý P (1991a) Fertile granites of Precambrian rare element pegmatite fields: is geochemistry controlled by tectonic setting or source lithologies. Precambr Res 51:429-468p

15. Černý P (1991b) Rare-element granitic pegmatites. I. Anatomy and internal evolution of pegmatite deposits. Geosci Can 18:49-67

16. Clarke MB (1981) The mineralogy of peraluminous granites: a review. Can Contrib Miner Petrol 79:3-17

17. Clark SP Jr, Peterman ZE, Heier KS (1966) Abundances in uranium thorium and potassium Handbook of physical constants Geological Society of America. Memoir 97:521-541

18. De La Roche H, Leterrier J, Grandelaude P, Marchal M (1980) A classification of volcanic and plutonic rocks using $R_{1}-R_{2}$ diagram and major element analyses. Its relationships with current nomenclature: Chem. Geol 29:183-210

19. El-Sharkawy MA, El-Bayoumi RM (1979) The ophiolites of Wadi Ghadir area Eastern Desert. Ann Geol Surv Egypt 9:125-134

20. Fosso Tchunte PM, Tchameni R, André-Mayer AS, Dakoure HS, Turlin F, Poujol M, Negue Nomo E, Saha Fouotsa AN, Rouer $\mathrm{O}$ (2018) Evidence for Nb-Ta occurrences in the Syn-Tectonic Pan-African Mayo Salah Leucogranite (Northern Cameroon): 
constraints from $\mathrm{Nb}$-Ta oxide mineralogy, geochemistry and $\mathrm{U}-\mathrm{Pb}$ LA-ICP-MS geochronology on Columbite and Monazite. Minerals 8:188

21. Frost BR, Frost CD (2008) A geochemical classification for feldspathic rocks. J Petrol 49:1955-1969

22. Frost BR, Barnes CG, Collins WJ, ArCuLus RJ, Ellis DJ, Frost CD (2001) A geochemical classification for granitic rocks. J Pet 42:2033-2048

23. Galliski MA, Márquez-Zavalía MF, Cerný P, Martínez V, Chapman R (2008) The Ta-Nb-Sn-Ti oxide-mineral paragenesis at La Viquita, a spodumene-bearing rare-element granitic pegmatite from San Luis, Argentina. Can Miner 47:379-393

24. Ginsburg Al, Timofeyev LN, Feldman LG (1979) Principles of geology of the granitic pegmatites. In: Nedra, Moscow (CCCP), p 296 (in Russian)

25. Gordiyenko VV (1971) Concentration of Li, $\mathrm{Rb}$ and $\mathrm{Cs}$ in potash feldspar and muscovite as criteria for pegmatites. Int Geol Rev 13:134-142

26. Heinrich EW (1962) Radioactive columbite. Am Mineral 47:1363-1379

27. Ibrahim ME, Shalaby MH, Ammar SE (1997) Preliminary studies on some uranium and thorium bearing pegmatites at $G$. Abu Dob, Central Eastern Desert, Egypt [J]. Proc Egypt Acad Sci 47:173-188

28. Ibrahim ME, Saleh GM, Abd El-Naby HH (2001) Uranium mineralization in the two mica granite of Gabal Ribdab, South Eastern Desert, Egypt [J]. Appl Radiat Isot 55(6):123-134

29. Ibrahim IH, Ali MA (2003) The granitic rocks in Wadi Ghadir area, South Eastern Desert, Egypt and occurrence of a secondary uranium mineral. Egypt J Geol 47(2):671-687

30. Irber W (1999) The lanthanide tetrad effect and its correlation with $\mathrm{K} / \mathrm{Rb}, \mathrm{Eu} / \mathrm{Eu}^{*}, \mathrm{Sr} / \mathrm{Eu}, \mathrm{Y} / \mathrm{Ho}$ and $\mathrm{Zr} / \mathrm{Hf}$ of evolving peraluminous granite suites. Geochemica et Cosmochimica Acta 63(3):489-508

31. Irber W, Forster HJ, Hech L, Moller P, Mortteani G (1997) Experimental, geochemical, mineralogical and oxygen isotope constrain in the late magmatic history of the Fichtelgebirge granites (Germany). Geol Rdesch 86:110-124

32. Jahn BM, FuyuanWu R, Capdevila R, Martineau F, Zhao Z, Wang $Y$ (2001) Highly evolved juvenile granites with tetrad REE patterns: the Woduhe and Baerzhe granites from the Great Xing and Mountains in NE China. J. Liths 59:171-198

33. Jahns RH (1982) Internal evolution of pegmatite bodies. In: Černý P (Ed) Granitic Pegmatites in Science and Industry Mineralogical Association of Canada, Australia

34. Jensen BB (1967) Distribution patterns of rare earth elements in cerium- rich minerals. Nor Geol Tidsskr 47:9-19

35. Kamar MS (2015) Geochemistry and mineraliza-tions of the Wadi Ghadir younger granites and associated pegmatites, South Eastern Desert. Egypt Arab J Geosci 8(3):1315-1338

36. Khaleal FM, Kamar MS, El-Sherif AM (2017) Geology, geochemistry and radioactivity of the monzogranite rocks, north Wadi Ghadir, south Eastern Desert Egypt. Nucl Sci Sci J 6:71-91

37. Lee SG, Masuda A, Kim HS (1994) An early proterozoic leuco granitic gneiss with the REE tetrad phenomenon. J Chem Geol 114:59-67

38. Linnen RL, Van Lichtervelde M, Cerný P (2012) Granitic pegmatites as sources of strategic metals. Elements 2012(8):275-280

39. Linnen RL, Samson IM, Williams-Jones AE, Chakhmouradian AR (2014) Geochemistry of the rare-earth element, $\mathrm{Nb}, \mathrm{Ta}, \mathrm{Hf}$, and $\mathrm{Zr}$ deposits. In: Holland HD, Turekian KK (eds) Treatise on Geochemistry, vol 13, 2nd edn. Elsevier, Oxford, pp 543-564
40. London D (2005) Granitic pegmatites: an assessment of current concepts and directions for the future. Lithos 80:281-303

41. London D (2008) Pegmatites. The Canadian Mineralogist, Special Publication. (no. 10, 347 p.)

42. Mackay AR, Simandl GJ (2014) Geology, market and supply chain of niobium and tantalum, A review. Miner Depos 49:1025-1047

43. Mahmoud MAM, Kamar MS, Hussein KH (2015) Mineralogy and geochemistry of stream sediments of southeast Wadi Ghadir, south Eastern Desert. Egypt. Al Azhar Bulet Sci 26(1):33-50

44. Masuda A, Kawakami O, Dohmoto Y, Takenaka T (1987) Lanthanide tetrad effects in nature: two mutually opposite types, $W$ and M. J Geochem J 21:119-124

45. Martin RF, De Vito C (2005) The patterns of enrichment in felsic pegmatites ultimately depend on tectonic setting. Can Miner 43:2027-2048

46. Melcher F, Graupner T, Gäbler HE, Sitnikova M, Henjes-Kunst $F$, Oberthür T, Gerdes A, Dewaele S (2015) Tantalum-(niobium-tin) mineralisation in African pegmatites and rare metal granites: constraints from $\mathrm{Ta}-\mathrm{Nb}$ oxide mineralogy, geochemistry and U-Pb geochronology. Ore Geol Rev 64:667-719

47. Ni Y, Hughes JM, Mariano AN (1995) Crystal chemistry of the monazite and xenotime structures. Am Miner 80:21-26

48. Nikishina EE, Drobot DV, Lebedeva EN (2014) Niobium and tantalum: State of the world market, application fields, and sources of raw materials. Part 2. Russ J Non-Ferr Met 55:130-140

49. Pabst A, Hutton CO (1951) Huttonite, a new mono-clinic thorium silicate. Am Miner 36:60-69

50. Page LR (1950) Uranium in pegmatites [J]. Econ Geol 45:12-34

51. Pearce JA, Harris NBW, Tindle AG (1984) Trace element discrimination diagrams for the tectonic interpretation of granitic rocks. J Petrol 25:956-983

52. Rankama K, Sahama TG (1955) Geochemistry. Chicago Univ. Press, Chicago, $p$ 37p

53. Raslan MF, El Shall HE, Omar SA, Daher AM (2010) Mineralogy of polymetallic mineralized pegmatite of Ras Baroud Granite, Central Eastern Desert, Egypt [J]. J Miner Pet Sci 105(3):123-134

54. Rogers JJW, Adams JAS (1969) Uranium and thorium. In Handbook of Geochemistry (ed. Wedepohl K.H.) [M]. VII-3, 92-B-1 to 92-0-8 and 90-B-1 to $90-0-5$, Springer Verlag, Berlin

55. Romer RL, Smeds SA (1996) U-Pb columbite ages of pegmatites from Sveconorwegian terranes in southwestern Sweden. Precambrian Res 76:15-30

56. Sayyah TA, Assaf HSA, Abdel Kader ZM, Mahdy MA, Omar SA (1993) New Nb-Ta occurrence in Gebel Ras baroud, Central Eastern Desert [J]. Egypt Miner 5:41-55

57. Shurmann HME (1966) The precambrian along the Gulf of Suez and the Northern Part of the Red Sea [M]. E.J Brill, Leiden

58. Takla MA, Basta FF, El Maghraby AMO (1987) Contribution to the geology of Wadi Ghadir area, South Eastern Desert, Egypt. 25th Ann. Meeting Geol. Soc. Egypt, Abstract, 17

59. Takla MA, Basta FF, Shenouda HH, El-Maghraby AM (1992) Geochemistry of gneisses and granitoids of Wadi Ghadir area, Eastern Desert. Egypt GAW Cairo Univ I:477-489

60. Taylor SR, McLennan SM (1985) The continental crust: its composition and evolution. Blackwell, Oxford, p 312p

61. Tischendorf G (1977) Geochemical and petrographic characteristics of silicic magmatic rocks associated with rare-element mineral-ization. In: Stemprok M, Burnol L, Tischendorf G (eds) Metalization associated with acid magmatism. 2, 41-96

62. Trueman DL, Cerny P (1982) Exploration for rare-element granitic pegmatites. In: Cerny P (ed) Granitic pegmatite science and 
industry. Mineralogical Association of Canada, Short Course Handbook, vol 8. pp 463-494

63. Vernilli F, Camargo Vernilli D, Ferreira B, Silva G (2007) Characterization of a rare earth oxide obtained from xenotime mineral. Mater. Charact 58:1-7. https://doi.org/10.1016/j.match ar.2006.01.022

64. Wades J, Wood BJ (2001) The earth's "missing" niobium may be in the core. Nature 409:75-78
65. Weaver B, Tarney J (1984) Empirical approach to estimating the composition of the continental crust. Nature 310:575-577

66. Zhenhua Z, Masuda A, Shabani MB (1993) REE tetrad effects in rare-metal granites. J Chin J Geochem 12:206-219

Publisher's Note Springer Nature remains neutral with regard to jurisdictional claims in published maps and institutional affiliations. 